\title{
Hygroscopic properties of different aerosol types over the Atlantic and Indian Oceans
}

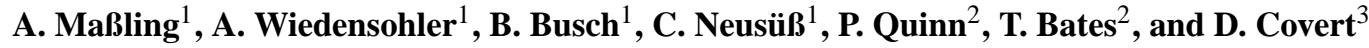 \\ ${ }^{1}$ Institute for Tropospheric Research, Permoserstr. 15, 04318 Leipzig, Germany \\ ${ }^{2}$ Northern Organization Atlantic Administration/Pacific Marine Environmental Laboratory (NOAA/PMEL), 7600 Sand Point \\ Way NE, Seattle, WA 98115, USA \\ ${ }^{3}$ Department of Atmospheric Science, University of Washington, Box 354235, Seattle, WA 98195-4235, USA
}

Received: 8 October 2002 - Published in Atmos. Chem. Phys. Discuss.: 10 January 2003

Revised: 20 August 2003 - Accepted: 25 August 2003 - Published: 16 September 2003

\begin{abstract}
Hygroscopic properties of atmospheric particles were studied in the marine tropospheric boundary layer over the Atlantic and Indian Oceans during two consecutive field studies: the Aerosols99 cruise (Atlantic Ocean) from 15 January to 20 February 1999, and the INDOEX cruise (Indian Ocean Experiment) from 23 February to 30 March 1999. The hygroscopic properties were compared to optical and chemical properties, such as absorption, chemical inorganic composition, and mass concentration of organic and elemental carbon, to identify the influence of these parameters on hygroscopicity.
\end{abstract}

During the two field studies, four types of aerosolsampling instruments were used on board the NOAA (National Oceanic and Atmospheric Administration) Research Vessel Ronald H. Brown: Hygroscopicity Tandem Differential Mobility Analyzer (HTDMA), seven-stage cascade impactor, two-stage cascade impactor, and Particle Soot Absorption Photometer (PSAP). The HTDMA was used to determine the hygroscopic properties of atmospheric particles at initial dry sizes $(D p)$ of 50,150 , and $250 \mathrm{~nm}$ and at relative humidities $(R H)$ of $30,55,75$, and $90 \%$. Simultaneously, a seven-stage cascade impactor of which 3 stages were in the sub- $\mu \mathrm{m}$ size range was used to determine the molar composition of the major inorganic ions such as ammonium and sulfate ions. A two-stage cascade impactor (1 in the sub- $\mu \mathrm{m}$ size range, 1 in the sup- $\mu \mathrm{m}$ size range) was used to determine the mass concentration of organic and elemental carbon. The PSAP was used (at a wavelength of $565 \mathrm{~nm}$ ) to measure the light absorption coefficient of the aerosol.

During the two field studies, air masses of several different origins passed the ship's cruise path. The occurrence of different air masses was classified into special time periods signifying the origin of the observed aerosol.

Correspondence to: A. Maßling

(massling@tropos.de)
All time periods showed a group of particles with high hygroscopic growth. The measured average hygroscopic growth factors defined by the ratio of dry and wet particle diameter at $90 \% R H$ ranged from 1.6 to 2.0 , depending on the dry particle size and on the type of air mass. Particles with low hygroscopic growth occurred only when continentally influenced air masses arrived at the ship's position. Distinctions in hygroscopic growth of particles of different air masses were more significant for small relative humidities (30\% or 55\% RH). High concentrations of elemental carbon corresponded with high light absorption coefficients and with the occurrence of less-hygroscopic and nearly hydrophobic particle fractions in the hygroscopic growth distributions.

A key finding is that clean marine air masses that had no land contact for five to six days could clearly be distinguished from polluted air masses that had passed over a continent several days before reaching the ship.

\section{Introduction}

Aerosol particles influence the radiative budget of the earth directly by scattering and absorbing the incoming sunlight and indirectly by serving as cloud condensation nuclei (CCN), (Charlson et al., 1992; Twomey et al., 1977). Although the greenhouse effect caused by greenhouse gases can be estimated fairly well, knowledge about the direct and indirect effect of aerosols has been limited up to now. The influence of aerosols on the radiative budget of the earth is estimated to be on the same order of magnitude as the radiative forcing of greenhouse gases, but of opposite sign (IPCC, 2001). The determination of physical and chemical properties of aerosol particles is therefore necessary to understand direct and indirect forcing, and thus lead to a reduction in the uncertainties in global climate models. A critical physical characteristic of an aerosol particle is its hygroscopic behavior. Hygroscopic properties of soluble atmospheric particles 
significantly influence the size of the particles at ambient relative humidity, and thus influence the scattering capability and residence time of these particles in the atmosphere (Ogren et al., 1992). For that reason, hygroscopic data together wit dry particle number size distributions are often required to calculate microphysical aerosol properties such as size distribution or scattering at ambient conditions.

Furthermore, knowledge of hygroscopic aerosol properties is needed because they determine the number of $\mathrm{CCN}$, and thus determine the resulting droplet size distribution of a cloud, which in turn affects cloud albedo (Twomey, 1974). The impact of aerosol particles in the marine boundary layer is potentially high, because the oceans cover a large area of the earth and because clouds in this layer are estimated to control about one-third of the earth's albedo (Charlson et al., 1987). The radiative properties of marine clouds are known to be susceptible to changes in their aerosol composition due to anthropogenic influence (Taylor and McHaffie, 1993). In addition, aerosol hygroscopicity measurements provide information about the mixing state and the chemical components of aerosol particles.

Hygroscopic behavior of aerosol particles has been investigated at different locations; e.g., Los Angeles by McMurry and Stolzenburg (1989), Po Valley by Svenningsson et al. (1992), Pacific and Southern Oceans by Berg et al. (1998), and eastern Northern Atlantic Ocean by Swietlicki et al. (2000). Comprehensive field studies in the past include the Aerosol Characterization Experiments ACE 1 and ACE 2, which determined the physical, chemical, and optical properties of aerosols in the marine boundary layer over the Pacific and Southern Oceans and over the eastern Northern Atlantic Ocean (Berg et al., 1998; Swietlicki et al., 2000). However, up to now, no such investigations have been done for the Southern Atlantic Ocean or the Indian Ocean.

In this study, hygroscopic properties of atmospheric particles were measured during two consecutive field studies. The first study, Aerosols99 cruise (Fig. 1a: Atlantic Ocean), occurred from 15 January to 20 February 1999, and traveled from Norfolk, USA, via Cape Town, South Africa, to Port Louis, Mauritius. The second study, INDOEX cruise (Fig. 1b: Indian Ocean), occurred from 23 February to 30 March 1999, and traveled from Port Louis, Mauritius, to Male, Maldives, and in the region of the Maldives Islands. The hygroscopic properties were determined for different air masses encountered during the two field studies. The air masses were classified according to their origin, age, and pollution level. The hygroscopic properties were then compared to measured optical and chemical properties, such as absorption, chemical inorganic composition, and mass concentration of organic and elemental carbon, to identify the implication of these parameters on hygroscopicity.

\section{Field studies}

Chemical, optical, and physical aerosol properties were measured in the marine boundary layer over the Atlantic and Indian Oceans during two field studies onboard the American Research Vessel Ronald H. Brown. The Aerosols99 field study, which studied the Atlantic Ocean, was divided into two parts: Leg 1 was from Norfolk, USA $\left(37^{\circ} \mathrm{N}\right.$ latitude, $76^{\circ} \mathrm{W}$ longitude, 15 day of year, DOY), to Cape Town, South Africa $\left(34^{\circ} \mathrm{S}\right.$ latitude, $18^{\circ} \mathrm{E}$ longitude, DOY 40$)$, and Leg 2 from Cape Town, South Africa $\left(34^{\circ} \mathrm{S}\right.$ latitude, $18^{\circ} \mathrm{E}$ longitude, DOY 42), to Port Louis, Mauritius, $\left(21^{\circ} \mathrm{S}\right.$ latitude, $57^{\circ} \mathrm{E}$ longitude, DOY 51). The INDOEX field study, which studied the Indian Ocean, was divided into three parts: Leg 3 was from Port Louis, Mauritius (DOY 54), to Male, Maledives $\left(20^{\circ} \mathrm{S}\right.$ latitude, $57^{\circ} \mathrm{E}$ longitude, DOY 60$)$, Leg 4 was from Male (DOY 63) into the region of the Maledives and back to Male (DOY 82), and Leg 5 was from Male (DOY 85) into the region of the Bay of Bengal and back to Male (DOY 89). In Figs. 1a and b, the cruise tracks of both field studies are shown by the black lines. During the route from Norfolk to Male, aerosols of different age and origin that identified various polluted air masses passed the ship's cruise path. Clean marine air masses (no land contact for five to six days) from the northern Atlantic Ocean, southern Atlantic Ocean, and Indian Ocean, as well as continentally influenced air masses (passed over a continent several days before reaching the ship or coming directly from the continent) from northern and western Africa, Indian Subcontinent, and Middle East were observed. The different air masses were categorized by using air-mass back-trajectory analysis, measured aerosol number concentrations and measured size distributions. The trajectories were calculated four times daily $(06.00,12.00,18.00$, and $24.00 \mathrm{~h}$ local time) for three altitudes (950, 750, and 500 mbar), (Bates et al., 2001; Quinn et al., 2002). The two field studies involved a combined total of 13 consecutive time periods, ranging from one to six days each. Table 1 summarizes the different types of air masses encountered during the two field studies.

For 6 of the 13 time periods, air masses dominated by a clean marine aerosol prevailed. These air masses were classified into different subtypes, based on their origin in different regions of the Atlantic and Indian Oceans (Bates et al., 2001; Quinn et al., 2002). Air masses dominated by Saharan mineral dust and biomass burning of the west African coast were encountered only near the equator and the Inter Tropical Convergence Zone (ITCZ). Emissions from the Indian Subcontinent and Middle East were only found in air masses in the Northern Hemisphere portion of the Indian Ocean. In Figs. 1a and b, calculated 950 mbar back trajectories are presented for certain time periods.

The data presented here is divided into five parts: Legs 1 and 2 of Aerosols99 (Atlantic Ocean) and Legs 3 to 5 of INDOEX (Indian Ocean). The X-axis for all figures is day of year (DOY), where 1 January (12.00 noon) is 1.5 . The 

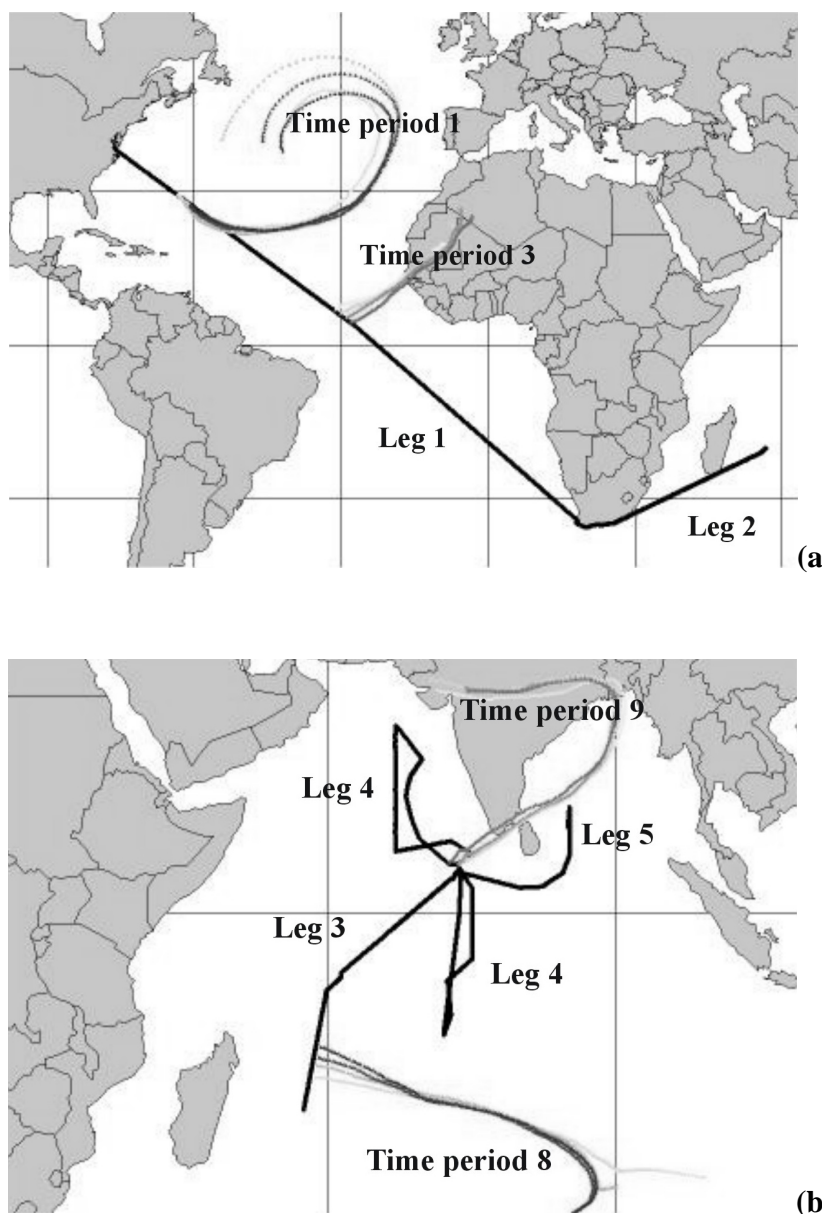

(b)

Fig. 1. Picture of the cruise tracks including air-mass back-trajectories for two different ship positions: (a) Aerosols99, (b) INDOEX.

interesting time periods 2, 3, 4 (continental influence during Aerosols99) and 9 (strong continental influence during INDOEX) will be discussed in detail.

\section{Chemical and physical measurements}

\subsection{Chemical inorganic composition}

The chemical inorganic ionic composition was obtained from a seven-stage cascade Berner impactor of which 3 stages plus a back-up filter were in the sub- $\mu \mathrm{m}$ size range (Berner et al., 1979). The major ions were analyzed by ion chromatography (Quinn et al., 1998). The detection limit of each impactor stage was determined from blank samples taken several times during the cruise (Quinn et al., 2001, 2002).

\subsection{Total aerosol mass}

The total aerosol mass was obtained from a two-stage cascade Berner impactor of which one stage was in the sub- $\mu \mathrm{m}$ size range and one stage in the sup- $\mu \mathrm{m}$ size range (Berner et al., 1979). The total aerosol mass was then determined by gravimetric analysis (Quinn et al., 2001, 2002).

\subsection{Carbonaceous aerosol}

Samples from a two-stage cascade Berner impactor were used for the carbon analysis (Berner et al., 1979). The mass concentrations of elemental carbon (EC) and organic carbon (OC) in the sub- $\mu \mathrm{m}$ and sup- $\mu \mathrm{m}$ size ranges were determined using a thermo-desorption-method (Neusüß et al., 2002). This thermographic method was applied using a temperature of $590^{\circ} \mathrm{C}$ to volatilize the $\mathrm{OC}$ fraction within 8 min under nitrogen. Based on the field blank mean values taken several times during the field studies, the detection limits (95\% confidence level) were $0.16 \mu \mathrm{g} / \mathrm{m}^{3}$ for OC and $0.07 \mu \mathrm{g} / \mathrm{m}^{3}$ for EC for a typical day/night sampling period (Neusüß et al., 2002).

The aerosol particles were sampled with a time resolution of 12 hours for inorganic components, and 12 or 24 hours (depending on the particle concentration) for EC and OC. The filters were changed daily at $06.00 \mathrm{~h}$ and $18.00 \mathrm{~h}$ local time. All impactors were placed in a climate box so that the 
Table 1. Classification and aerosol properties of different air masses observed during Aerosols99 (Atlantic Ocean) and INDOEX (Indian Ocean) field studies

\begin{tabular}{|c|c|c|c|c|c|c|c|}
\hline $\operatorname{Leg}^{1}$ & Time period & DOY & $\begin{array}{l}\text { Total aerosol mass } \\
\text { concentration of } \\
0-1 \mu \mathrm{m} \text { particles } \\
{\left[\mu \mathrm{g} / \mathrm{m}^{3}\right]+1-\mathrm{sd}}\end{array}$ & $\begin{array}{l}\text { Concentration of } \\
\text { elemental carbon } \\
\text { of particles }<1 \mu \mathrm{m} \\
{\left[\mu \mathrm{g} / \mathrm{m}^{3}\right]+1-\mathrm{sd}}\end{array}$ & $\begin{array}{l}\text { Concentration of } \\
\text { organic carbon in } \\
\text { particles }<1 \mu \mathrm{m} \\
{\left[\mu \mathrm{g} / \mathrm{m}^{3}\right]+/-\mathrm{sd}}\end{array}$ & $\begin{array}{l}\text { Absorption coefficient } \\
\text { for particles }<10 \mu \mathrm{m} \\
{\left[\mathrm{Mm}^{-1}\right]}\end{array}$ & Air mass type/origin 3 \\
\hline 1 & 1 & $17.5-23.0$ & $\begin{array}{l}1.47 \\
+/-1.94\end{array}$ & $\mathrm{NA}^{4}$ & $\begin{array}{l}0.17 \\
+/-0.18\end{array}$ & $\mathrm{NA}^{2}$ & $\begin{array}{l}\text { Northern Atlantic marine } \\
\text { air mass }\end{array}$ \\
\hline 1 & 2 & $23.0-25.0$ & $\begin{array}{l}5.39 \\
+/-0.57\end{array}$ & NA & $\mathrm{NA}^{5}$ & NA & African dust air mass \\
\hline 1 & 3 & $25.0-27.0$ & $\begin{array}{l}5.45 \\
+/-1.69\end{array}$ & $\begin{array}{l}0.30 \\
+/-0.13\end{array}$ & NA & 5.00 & $\begin{array}{l}\text { Mixed: African dust and } \\
\text { biomass burning in the ITZC }\end{array}$ \\
\hline 1 & 4 & $27.0-29.8$ & $\begin{array}{l}4.83 \\
+/-0.71\end{array}$ & $\begin{array}{l}0.43 \\
+/-0.14\end{array}$ & $\begin{array}{l}0.28 \\
+/-0.06\end{array}$ & 5.95 & Biomass burning in the ITZC \\
\hline 1 & 5 & $29.8-36.0$ & $\begin{array}{l}1.02 \\
+/-0.32\end{array}$ & NA & NA & NA & $\begin{array}{l}\text { Southern Atlantic tropical/ } \\
\text { temperate marine air mass }\end{array}$ \\
\hline 2 & 6 & $43.0-48.5$ & $\begin{array}{l}0.72 \\
+/-0.12\end{array}$ & $\mathrm{NA}$ & NA & NA & $\begin{array}{l}\text { Southern Atlantic subtropical } \\
\text { marine air mass }\end{array}$ \\
\hline 2 & 7 & $48.5-50.9$ & $\begin{array}{l}0.67 \\
+/-0.11\end{array}$ & NA & NA & NA & Indian Ocean marine air mass \\
\hline $3 / 4$ & 8 & $\begin{array}{l}54.00-56.60 \\
78.25-79.50\end{array}$ & $\begin{array}{l}1.13 \\
+/-0.17\end{array}$ & NA & NA & NA & $\begin{array}{l}\text { Southern Hemisphere/ } \\
\text { Marine Indian Ocean }\end{array}$ \\
\hline 4 & 9 & $63.50-66.50$ & $\begin{array}{l}18.44 \\
+/-4.34\end{array}$ & $\begin{array}{l}1.64 \\
+/-0.26\end{array}$ & $\begin{array}{l}0.81 \\
+/-0.09\end{array}$ & 15.80 & $\begin{array}{l}\text { Indian Subcontinent and } \\
\text { directly to the ship }\end{array}$ \\
\hline 4 & 10 & $\begin{array}{l}67.00-68.00 \\
70.60-76.00\end{array}$ & $\begin{array}{l}9.24 \\
+/-2.00\end{array}$ & $\begin{array}{l}0.54 \\
+/-0.36\end{array}$ & $\begin{array}{l}0.59 \\
+/-0.55\end{array}$ & 5.44 & $\begin{array}{l}\text { Mixed: Indian Subcontinent } \\
\text { and Middle East }\end{array}$ \\
\hline 4 & 11 & $\begin{array}{l}76.00-78.25 \\
79.75-81.25\end{array}$ & $\begin{array}{l}3.18 \\
+/-0.31\end{array}$ & $\begin{array}{l}0.13 \\
+/-0.04\end{array}$ & NA & 2.31 & $\begin{array}{l}\text { Northern Hemisphere/ } \\
\text { Marine Indian Ocean }\end{array}$ \\
\hline $4 / 5$ & 12 & $\begin{array}{l}81.25-82.00 \\
85.00-88.75\end{array}$ & $\begin{array}{l}7.33 \\
+/-2.48\end{array}$ & $\begin{array}{l}0.36 \\
+/-0.12\end{array}$ & $\begin{array}{l}0.25 \\
+/-0.12\end{array}$ & 5.66 & Arabian Sea/Coastal India \\
\hline 5 & 13 & $88.75-89.5$ & $\begin{array}{l}13.35 \\
+/-0.50\end{array}$ & $\begin{array}{l}0.74 \\
+/-0.11\end{array}$ & $\begin{array}{l}0.46 \\
+/-0.02\end{array}$ & 11.68 & $\begin{array}{l}\text { Bay of Bengal and } \\
\text { directly to the ship }\end{array}$ \\
\hline
\end{tabular}

${ }^{1}$ Legs 1 and 2 were during Aerosols99, and Legs 3-5 during INDOEX.

2 Data not available because the value was below the detection limit of the PSAP $\left(0.34 \mathrm{Mm}^{-1}\right)$.

3 Classification determined by air-mass back-trajectory analysis.

${ }^{4}$ Data not available because the value was below the detection limit of $0.07 \mu \mathrm{g} / \mathrm{m}^{3}$.

${ }^{5}$ Data not available because the value was below the detection limit of $0.16 \mu \mathrm{g} / \mathrm{m}^{3}$.

sampling was done under stable conditions at $55 \%+/-5 \%$ $R H$ (Quinn et al., 2001, 2002; Neusüß et al., 2002).

\subsection{Light absorption}

Additionally, the light absorption coefficient for particles smaller than $10 \mu \mathrm{m}$ in diameter was measured using a Particle Soot Absorption Photometer (PSAP) operated at a wavelength of $565 \mathrm{~nm}$ and at $55 \%+/-5 \% R H$. During the INDOEX field study, the PSAP was operated in combination with a cut-off filter, thus yielding the light absorption coefficient for particles smaller than $1 \mu \mathrm{m}$. The PSAP determines the absorption coefficient by monitoring the change in transmission through a filter. The data were corrected according to the manufacturer's calibration, scattering artifacts, flow rate through the PSAP, and deposit diameter (Quinn et al., 2001, 2002). The PSAP sampled the aerosol with a time resolution of 15 minutes. The detection limit of the PSAP was $0.34 \mathrm{Mm}^{-1}$.

\subsection{Hygroscopicity}

The HTDMA system was used for the hygroscopic growth measurements. This system consists of two DMAs (Differential Mobility Analyzer) and a humidifier between the DMAs (Liu et al., 1978). The first DMA selects a monodisperse particle fraction from the atmospheric aerosol and is operated at values $<5 \% R H$. This monodisperse particle fraction is passed through a humidity conditioner operated at an air flow humidified to $90 \% R H$. This technique yields an 
aerosol flow with $R H$ greater than $85 \%$. The humidity of the sheath air flow of the second DMA is regulated by mixing dry air $(<5 \% R H)$ and humid air $(\sim 95 \% R H)$, and thus can then be adjusted between 30 to $90 \% R H$.

Because the humidity of the sheath air flow and the aerosol flow can be adjusted separately, deliquescence as well as efflorescence behavior can be studied with the HTDMA. The aerosol humidity as well as the $R H$ of the sheath air were continuously measured by calibrated capacitive sensors and were adjusted after each scan to the desired $R H$.

The altered size distribution due to a possible uptake of water was then determined by using the second DMA and a Condensation Particle Counter (CPC), resulting in a hygroscopic growth distribution at that particle size and humidity. The hygroscopic growth factor $\operatorname{gf}(R H)$ of each particle fraction in the hygroscopic growth distribution was then determined by the ratio of the particle size measured at that specific $R H$ and dry particle size following Eq. (1):

$g f(R H)=\frac{D p(R H)}{D p(d r y)}$.

The number fraction of each hygroscopic group in the distribution was determined by the ratio of the number fraction of that group (determined by its peak area) to the sum of the number fractions of all groups occurring in the hygroscopic growth distribution.

The flow in the HTDMA is extremely reliable and stable; fluctuations in the aerosol flow or sheath air flow were less than $2.5 \%$. The $R H$ within the humidity conditioner as well as in all flow rates within the system were controlled and adjusted during the entire measurement. The HTDMA was size-calibrated with latex spheres under ambient conditions (i.e., no humidification). Differences in size selection by the first and second DMAs were characterized by determining a calibration function, which was then used to correct all data for this effect of size-selection difference. The humidity sensors used in the HTDMA were calibrated using the deliquescence behavior of three different salts, namely, sodium chloride $(\mathrm{NaCl})$, ammonium sulfate $\left(\mathrm{NH}_{4}\right)_{2} \mathrm{SO}_{4}$, and potassium chloride $(\mathrm{KCl})$. The measured deliquescence $R H$ of these three salts were within $+/-0.5 \% R H$ of data reported by Seinfeld and Pandis (1998).

A temperature gradient between the humidity regulation sensor and the DMA itself can sometimes not be eliminated. Therefore, the $R H$ inside the second DMA was determined four times each day by a salt calibration to obtain the real $R H$ during the measurement. The growth factors measured at $90 \% R H$ were corrected for this temperature-gradient effect. Nevertheless, the error in hygroscopic growth was calculated based on estimated uncertainties in $R H$ within the HTDMA. The estimated uncertainty in measurements between $30 \%$ and $90 \% R H$ was $+/-1 \% R H$. For measurement of the hygroscopic growth of an ammonium bisulfate particle determined with the HTDMA, this uncertainty results in a relative uncertainty of less than $5 \%$ for growth factors measured between $30 \%$ and $90 \% R H$.

When the HTDMA is used without humidity regulation, the monodisperse aerosol distribution after the first DMA broadens due to the width of the transfer function of the second DMA. Therefore, before the data was analyzed, all distributions were inverted using a Tandem Differential Mobility Analyzer inversion algorithm by Voutilainen et al. (2000) to account for this broadening.

The HTDMA was operated continuously except for short periods (about 60 minutes each day) when the system was recalibrated. Hygroscopic growth factors were determined for particles with initial dry sizes $(D p)$ of 50,150 , and $250 \mathrm{~nm}$. The distributions were obtained at $30,55,75$, and $90 \% R H$. The aerosol was humidified to $R H>85 \%$ for all measurements before coming into contact with the sheath air in the second DMA, so that all particles had exceeded their deliquescence point by the time they reached the second DMA. The acquisition of each distribution took about 20 minutes because particle concentrations were sometimes small $\left(<250 \# / \mathrm{cm}^{3}\right)$.

During both field studies, all instruments were set up in a container placed on deck of the ship. The aerosol was sampled at $18 \mathrm{~m}$ above sea level by using an 6-m-high inlet tower (Quinn et al., 2001, 2002). When the measurements were influenced by emissions from the ship itself (evidenced by extremely high particle concentrations), the inlet was then closed. Because of local pollution, all data obtained within $250 \mathrm{~km}$ of the harbors of Norfolk, Cape Town, Port Louis, and Male were not included in the data evaluation.

\section{Results and Discussion}

\subsection{Chemical inorganic composition}

Figure 2 shows the molar composition of the major inorganic ions measured for $80 \mathrm{~nm}<D_{a e}<184 \mathrm{~nm}$ (first impactor stage) and for $184 \mathrm{~nm}<D_{a e}<308 \mathrm{~nm}$ (second impactor stage). These two stages cover the size range that was also determined by the HTDMA-measurements. At the beginning of Leg 1 as well as during Leg 3, a significant number of sodium and chloride ions were sometimes detected in both size ranges. During Leg 2, this observation was only made for the second impactor stage. These concentrations can be assigned to sea salt particle production during periods of high wind speeds $\left(>10 \mathrm{~m} / \mathrm{s}^{2}\right)$ in the days preceding those measurements. During time periods 2 and 3 (Aerosols99, Leg 1: DOY 23-DOY 27), small concentrations of calcium were found in the second impactor stage indicating that air masses influenced by dust were observed. During time periods 3 and 4 (Aerosols99, Leg 1: DOY 25DOY 30), air masses influenced by biomass burning were encountered. For these two time periods, high concentrations of potassium were detected, indicating that the observed air 


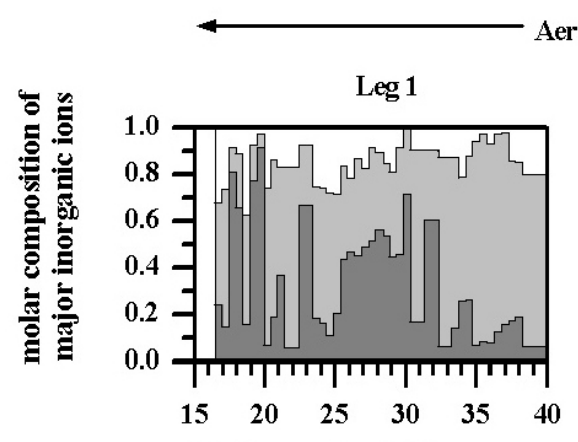

(a) $80 \mathrm{~nm}<D_{\text {ae }}<184 \mathrm{~nm}$

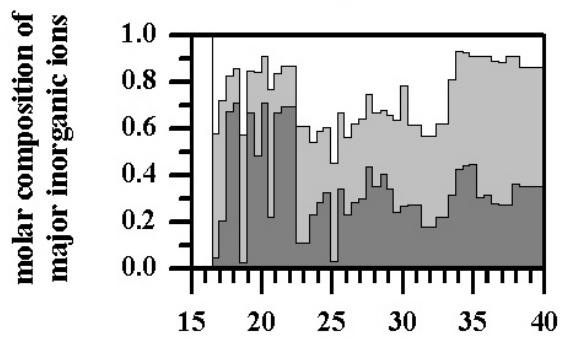

(b) $184<\mathrm{D}_{\text {ae }}<308 \mathrm{~nm}$

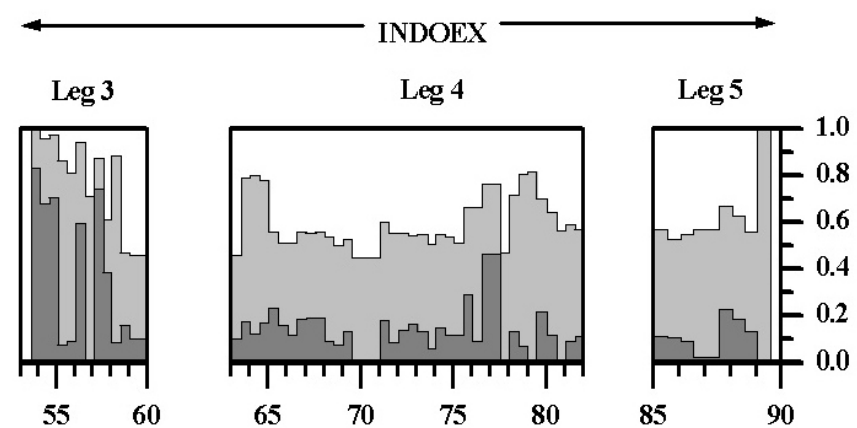

day of year (DOY)
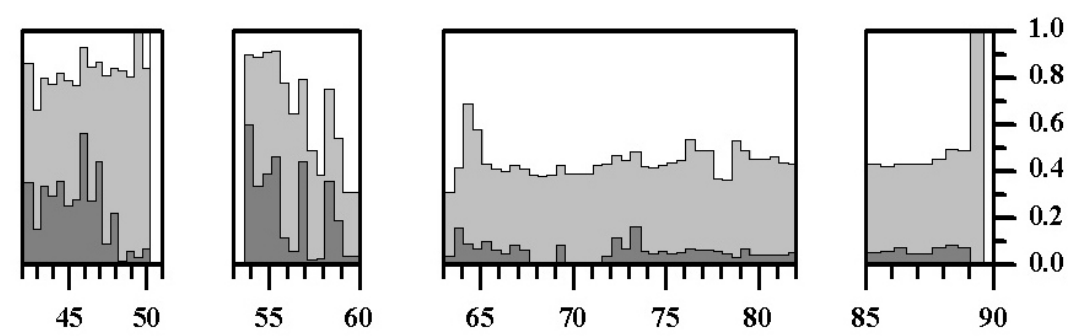

day of year (DOY)

\section{$\checkmark$ ammonium ions $\square$ sulfate ions $\square$ residual ions}

Fig. 2. Molar composition of the major inorganic ions for particles with (a) $80 \mathrm{~nm}<D_{a e}<184 \mathrm{~nm}$ (collected on the first impactor stage) and (b) $184 \mathrm{~nm}<D_{a e}<308 \mathrm{~nm}$ (second impactor stage) measured during Aerosols99 (Atlantic Ocean) and INDOEX (Indian Ocean).

masses were anthropogenically influenced by biomass burning (Philip et al., 1999). However, for all other time periods, ammonium and sulfate ions dominated the molar composition for both size ranges, assuming that the major inorganic components of the aerosol were a mixture of ammonium sulfate, ammonium bisulfate, and sulfuric acid. The residual ions were chlorine, nitrate, methanesulfonate, sodium, potassium, magnesium, and calcium. Especially for Legs 4 and 5 during INDOEX, residual ions were only $15 \%$ for particles of $80 \mathrm{~nm}<D_{a e}<184 \mathrm{~nm}$ (first impactor stage, Fig. 2) and $10 \%$ for $184 \mathrm{~nm}<D_{a e}<308 \mathrm{~nm}$ (second impactor stage, Fig. 2).

Figure 3 shows the molar ratio of ammonium ions to sulfate ions calculated for particles in these two size ranges. During Aerosols99 (Atlantic Ocean, Legs 1-2), for all time periods, the ratio for particles of $80 \mathrm{~nm}<D_{a e}<184 \mathrm{~nm}$ was smaller than 0.8, whereas during INDOEX (Indian Ocean, Legs 3-5), it ranged between 0.8 and 1.2. During both field studies, this ratio was most of the time higher for particles of $184 \mathrm{~nm}<D_{a e}<308 \mathrm{~nm}$ than for particles of $80 \mathrm{~nm}<D_{a e}<184 \mathrm{~nm}$. One reason for this higher ratio might be aging processes. Particles with larger diameters might have resided longer in the atmosphere, and thus water soluble material might have condensed on them or they might have been cloud processed and thereby became more neutralized. Here, "cloud processed" means the activation of a particle to a cloud droplet and the condensation of condensable material onto the particle. The results from higher impactor stages support this conclusion.
For Aerosols99 and INDOEX, the ion balance was calculated taking into account all measured cations and anions and their charges following Eq. (2):

ion - balance $=\frac{\left.\sum a \times\left(n\left(\text { cation }^{a+}\right)\right)-\sum b \times\left(\text { (anion }^{b-}\right)\right)}{\left.\sum a \times\left(n\left(\text { cation }^{a+}\right)\right)+\sum b \times\left(\text { (anion }^{b-}\right)\right)}$.

The parameter $n$ is here the amount of substance and $a$ and $b$ are the charges of cations and anions. The ion balance for both impactor stages is presented in Fig. 4. For most time periods during both experiments, the ion balance shows a negative value assuming that $\mathrm{H}^{+}$was a main component of the observed aerosol. This tendency is more pronounced for the first impactor stage.

The ratio of ammonium ions to sulfate ions together with the presented ion balance indicate that especially for the first impactor stage the inorganic fraction of the aerosol over the Atlantic Ocean (Figs. 3 and 4, Aerosols99, Legs 1-2) was mainly composed of sulfuric acid, whereas the aerosol over the Indian Ocean (Figs. 3 and 4, INDOEX, Legs 3-5) was composed of a mixture of ammonium sulfate and ammonium bisulfate.

\subsection{Total aerosol mass}

Table 1 lists the total aerosol mass concentration and the mass concentrations of EC (elemental carbon mass) and OC (organic carbon mass) for particles of $D_{a e}<1 \mu \mathrm{m}$, and Fig. 5 shows their distribution for the 13 time periods during the 

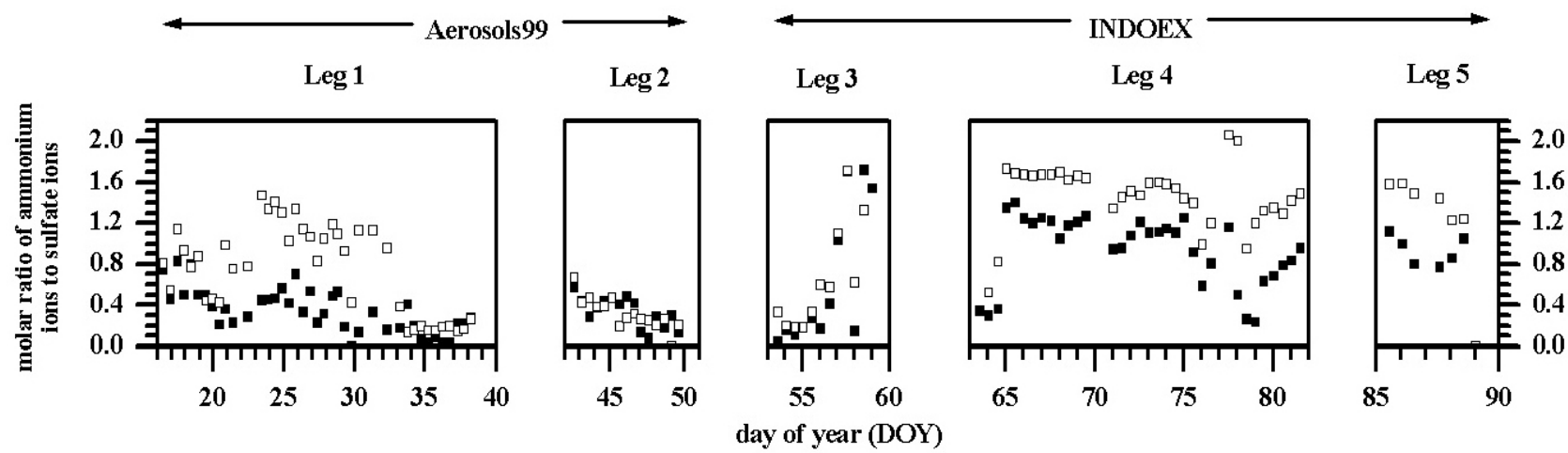

- $80 \mathrm{~nm}<\mathrm{D}_{\mathrm{ae}}<184 \mathrm{~nm} \square 184 \mathrm{~nm}<\mathrm{D}_{\mathrm{ae}}<308 \mathrm{~nm}$

Fig. 3. Molar ratio of ammonium ions to sulfate ions for particles with $80 \mathrm{~nm}<D_{a e}<184 \mathrm{~nm}$ (collected on the first impactor stage) and for $184 \mathrm{~nm}<D_{a e}<308 \mathrm{~nm}$ (second impactor stage) measured during Aerosols99 (Atlantic Ocean) and INDOEX (Indian Ocean).

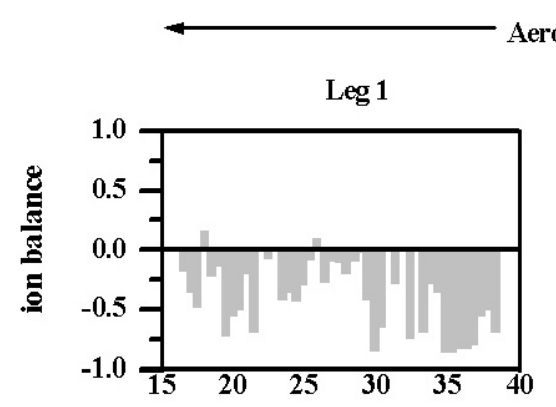

(a) $80 \mathrm{~nm}<\mathrm{D}_{\mathrm{ae}}<184 \mathrm{~nm}$

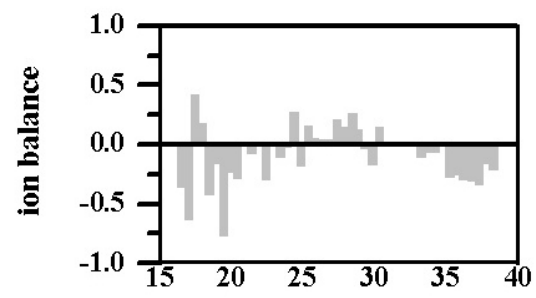

(b) $184<D_{\text {ae }}<308 \mathrm{~nm}$

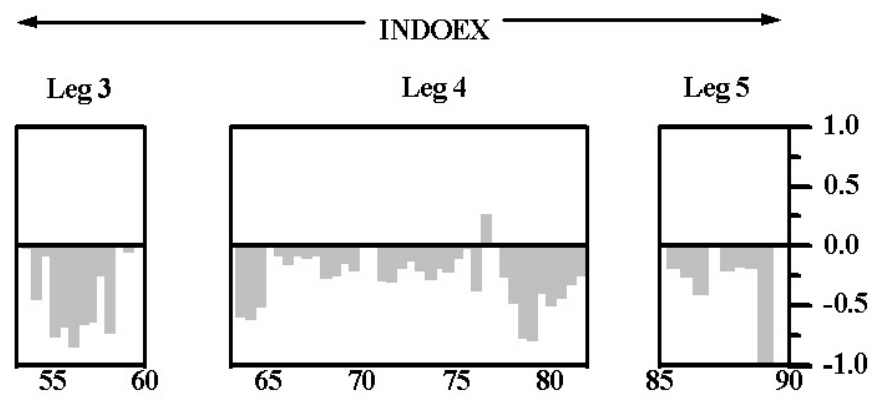

day of year (DOY)
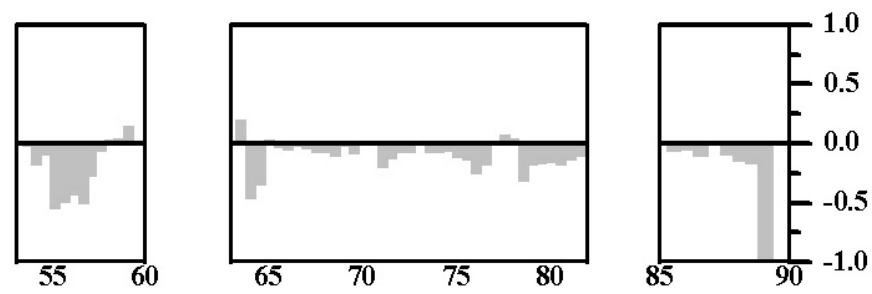

day of year (DOY)

Fig. 4. Ion balance of all inorganic ions for particles with $80 \mathrm{~nm}<D_{a e}<184 \mathrm{~nm}$ (collected on the first impactor stage) and for $184 \mathrm{~nm}<D_{a e}<308 \mathrm{~nm}$ (second impactor stage) measured during Aerosols99 (Atlantic Ocean) and INDOEX (Indian Ocean).

two field studies. The total aerosol mass concentration was significantly higher for those air masses that were continentally influenced (e.g., time periods 2, 3, 4, 9, 10, 12, 13).

During Aerosols99, the highest aerosol mass concentration $\left(5.45 \mu \mathrm{g} / \mathrm{m}^{3}\right.$ ) occurred in time period 3 (DOY 25-27), when air masses polluted by African dust and biomass burning reached the ship. High aerosol mass concentrations exceeding $4 \mu \mathrm{g} / \mathrm{m}^{3}$ also occurred in time period 2 (DOY 2325, African dust air mass) and time period 4 (DOY 27-29.8, biomass burning in the ITCZ), whereas concentrations lower than $1.5 \mu \mathrm{g} / \mathrm{m}^{3}$ were detected when marine air masses were encountered. Here, during time period 2, it is shown that mineral dust is extending into the fine aerosol fraction.

During INDOEX in time period 9 (DOY 63.5-66.5), air masses influenced by the Indian Subcontinent arrived at the ship, evidenced by an increase in total aerosol mass concentration up $18.44 \mu \mathrm{g} / \mathrm{m}^{3}$. In general, the highest concentration of aerosol mass occurred in this time period 9, which was characterized by air masses that had crossed the Indian Subcontinent 12 to 36 hours before they reached the ship. 


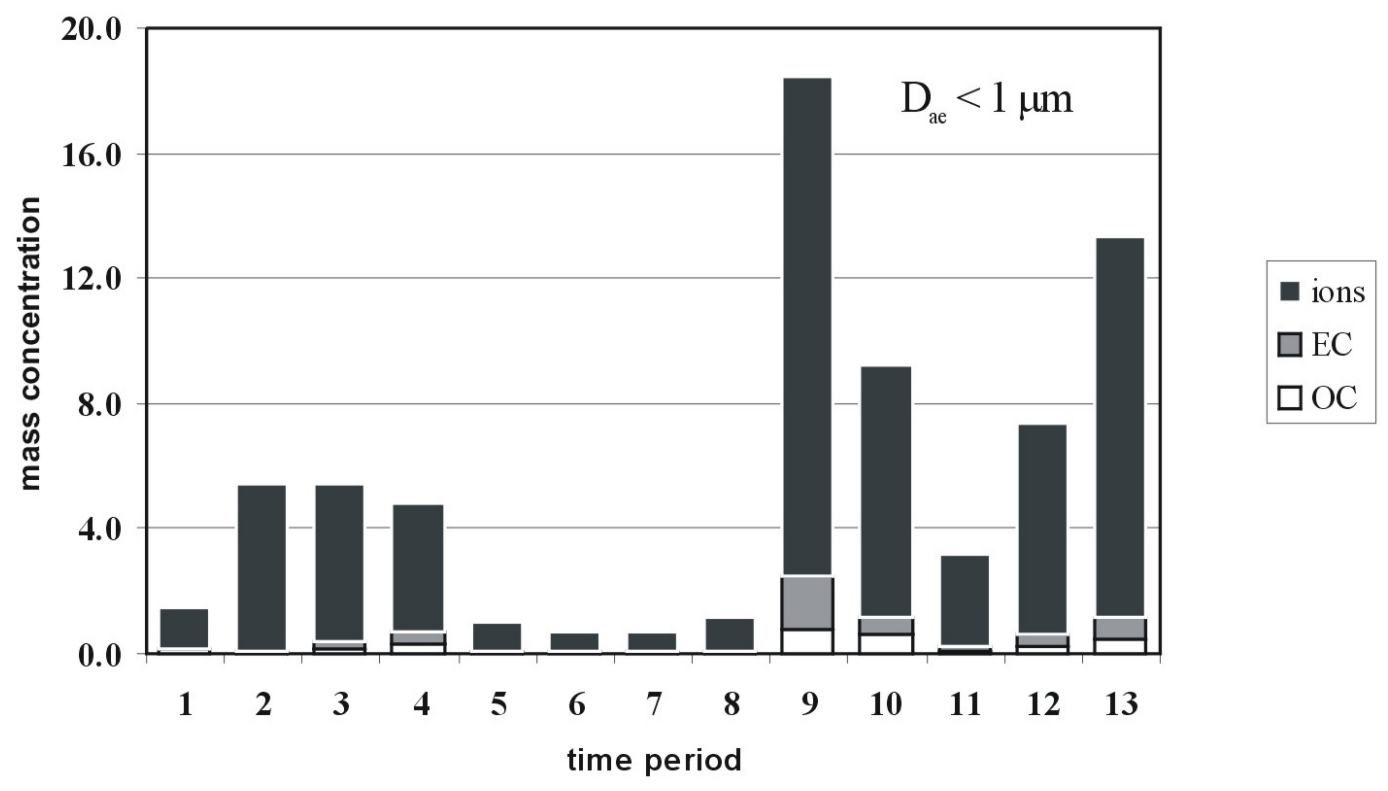

Fig. 5. Mass concentration of elemental carbon (EC), organic carbon (OC), and inorganic ions in $\mu \mathrm{g} / \mathrm{m}^{3}$ for particles with $D_{a e}<1 \mu \mathrm{m}$ measured during Aerosols99 and INDOEX.

\subsection{Carbonaceous aerosol}

Time period 3 (DOY 25-27) shows a mixture of air masses from northern and western Africa, as evidenced by the higher mass concentration of EC (Table 1). Time period 4 (DOY 27-29.8) was exclusively influenced by biomass burning (Bates et al., 2001). For the time period influenced by mixed air masses (time period 3, DOY 25-27), the mass concentration of EC reached $0.30 \mu \mathrm{g} / \mathrm{m}^{3}$ in the sub- $\mu \mathrm{m}$ size range (Table 1). The increase in EC concentration to $0.43 \mu \mathrm{g} / \mathrm{m}^{3}$ during the subsequent time period 4 (DOY 2729.8) indicates a change in air mass to one that is influenced only by biomass burning. For both time periods, an increase in mass concentration of OC was also detected $\left(0.12 \mu \mathrm{g} / \mathrm{m}^{3}\right.$ and $0.28 \mu \mathrm{g} / \mathrm{m}^{3}$, respectively). Lower OC concentrations of $0.1 \mu \mathrm{g} / \mathrm{m}^{3}$ OC were typical in the sub- $\mu \mathrm{m}$ size range for clean marine air masses that had no land contact for five to six days (Table 1). Here, based on the field blank mean values taken several times during the field studies, the detection limits (95\% confidence level) were $0.16 \mu \mathrm{g} / \mathrm{m}^{3}$ for OC and $0.07 \mu \mathrm{g} / \mathrm{m}^{3}$ for EC for a typical day/night sampling period (Neusüß et al., 2002). Therefore, all of the OC and EC concentrations for clean marine air masses during Aerosols99 were close to the detection limits.

The highest concentration of EC in the sub- $\mu \mathrm{m}$ size range $\left(1.64 \mu \mathrm{g} / \mathrm{m}^{3}\right)$ occurred in time period 9 , when air masses from the Indian Subcontinent reached the ship (INDOEX, DOY 63.5-66.5, Table 1). Here, individual values of about $2.0 \mu \mathrm{g} / \mathrm{m}^{3}$ were detected. In contrast to the analysis of the major inorganic ions, the analysis of OC and EC in the collected samples showed significant variations, which can be explained by differently polluted air masses encountered during the field studies. A key result of this EC and OC analysis is that mass concentrations of EC were detected only for continentally influenced air masses (Table 1). It is evident, that also air masses that had land contact several days before they reached the ship show increased values of aerosol mass and particularly of elemental carbon mass concentration.

\subsection{Light absorption}

In Table 1, the mean values of the light absorption coefficient measured with the PSAP are listed. The measured coefficients correlate well with the data obtained for EC; increasing mass concentrations of EC correspond with increasing absorption coefficients. For INDOEX, Neusüß et al. found an absorption efficiency of around $14 \mathrm{~m}^{2} / \mathrm{g}$ for all air masses except the most polluted cases (Indian Subcontinent and directly to the ship) (2002). For time period 3 (mixed air mass: African dust and biomass burning, Aerosols99, DOY 25-27), the light absorption coefficient reached individual values of $8 \mathrm{Mm}^{-1}$, for time period 4 (biomass burning, Aerosols99, DOY 25-27.8) $13 \mathrm{Mm}^{-1}$, and for time period 9 (Indian Subcontinent and directly to the ship, INDOEX, DOY 63.566.5) $20 \mathrm{Mm}^{-1}$. In contrast, the coefficients for clean marine air masses were near or less than the detection limit of $0.34 \mathrm{Mm}^{-1}$ (Quinn et al., 2001, 2002). Thus, the EC concentration together with the measured light absorption coefficient indicate that time periods $2,3,4,9,10,12$, and 13 were mainly continentally influenced. This indication is supported by the back-trajectory analysis done by Bates et al. (2001) and Quinn et al. (2002). 


\subsection{Hygroscopicity}

In this presentation, all particles were classified into three different groups appearing as three different modes in the hygroscopic growth distributions: nearly hydrophobic, lesshygroscopic, and more-hygroscopic.

The hygroscopic properties as determined by the HTDMA are presented here as two parameters: the hygroscopic growth factor for each of the observed growth groups as a function of $R H$ and the initial dry sizes, and the particle number fraction in each group.

\subsubsection{Growth factors of different aerosol types measured at $90 \% R H$}

\section{More-hygroscopic particles}

Figure 6 shows the hygroscopic growth factors measured at $90 \% R H$ for particles with initial dry sizes of 50,150, and $250 \mathrm{~nm}$ for each time period of the field studies. In general, a more- hygroscopic fraction of aerosol particles was detected at $90 \% R H$ for all time periods and for all sizes. The average growth factors for this fraction at $90 \% R H$ ranged between 1.66 and 1.74 for $50 \mathrm{~nm}$ particles, between 1.80 and 1.93 for $150 \mathrm{~nm}$ particles, and between 1.84 and 2.03 for $250 \mathrm{~nm}$ particles. The mean values averaged for the different time periods are listed in Tables 2-4 and 6-8. These values agree with those for marine aerosols measured during ACE 1 (Aerosol Characterization Experiment 1) over the Pacific Ocean and Southern Ocean, namely, 1.66 for $50 \mathrm{~nm}$ particles and 1.78 for $150 \mathrm{~nm}$ particles (Berg et al., 1998). The smallest average growth factors for the more-hygroscopic particle group at $90 \% R H$ occurred for the air mass influenced by biomass burning in the ITCZ during time period 4 (Aerosols99, Fig. 6, DOY 27-29.8), namely, 1.68 (50 nm particles), 1.8 (150 nm), and $1.84(250 \mathrm{~nm})$. In contrast, the average growth factors for the clean marine air masses ranged between 1.66 and 1.74 $(50 \mathrm{~nm}), 1.86$ and $1.93(150 \mathrm{~nm})$, and 1.91 and $2.03(250 \mathrm{~nm})$. The highest average growth factors occurred during time period 6 (Aerosols99, Fig. 6, DOY 43-48.5), when southern Atlantic marine air masses were encountered, namely, 1.93 $(150 \mathrm{~nm})$ and $2.03(250 \mathrm{~nm})$. These high growth factors can be explained by the chemical composition of the particles, which show small concentrations of sodium and chloride at this size, implying that sea salt particles were included in the measurements. In general, highest growth factors for accumulation mode particles were found during Leg 1-3, when marine air masses were encountered and sometimes small concentrations of sea salt were detected.

During INDOEX, the change in air mass from time period 8 (Southern Hemisphere portion of the Marine Indian Ocean, Fig. 6, DOY 54-56.6 and 78.25-79.5) to time period 9 (Indian Subcontinent and directly to the ship, Fig. 6, DOY 63.5-66.5) corresponds with the change in hygroscopic growth factors from 1.89 to $1.82(150 \mathrm{~nm})$ and from 1.98 to $1.89(250 \mathrm{~nm})$.

\section{Less-hygroscopic particles}

For both field studies, less-hygroscopic particle fractions were detected only during those time periods when the ship encountered continentally influenced air masses (e.g., time periods $3,4,9,10,12,13)$. This corresponds with increasing EC concentrations, which were detected only during those time periods.

For Aerosols99, less-hygroscopic particle fractions were detected only during time periods 3 and 4 (Fig. 6, DOY 2527, 27-29.8), when the air masses were affected by biomass burning. For these two time periods, the average growth factors for the less-hygroscopic particle group were between 1.44 and $1.50(50 \mathrm{~nm})$, between 1.45 and $1.47(150 \mathrm{~nm})$, and between 1.30 and $1.39(250 \mathrm{~nm})$. During INDOEX, the smallest growth factors of less-hygroscopic particles $(150 \mathrm{~nm}$ and $250 \mathrm{~nm}$ ) were detected during time period 9 (Fig. 6, DOY 63.5-66.5), when Indian Subcontinent air masses with a transport time between 12 and 36 hours were encountered. In this time period, average growth factors reached 1.54 for the $150 \mathrm{~nm}$ particles and 1.59 for the $250 \mathrm{~nm}$ particles.

In contrast, the growth factor for the less-hygroscopic particles during ACE 1 were between 1.24 and $1.39(50 \mathrm{~nm})$ and between 1.33 and $1.36(165 \mathrm{~nm})$ and also occurred only for polluted air masses (Berg et al., 1998).

Generally, growth factors of less-hygroscopic particles indicate that these particles were composed of both soluble and insoluble material. This mixture suggests that these particles were emitted by anthropogenic sources and altered during their transport between the continent and the ship. This result indicates that aging processes play a major role in hygroscopic properties of aerosol particles and their effect on climate.

\section{Hydrophobic particles}

During Aerosols99, a third mode of particles with growth factors smaller than 1.3, which might be classified as nearly hydrophobic particles, were not detected for any time period. The reason is that only aged aerosols (cloud processing, condensation of soluble material) were encountered.

In contrast, during time period 9 (INDOEX, Fig. 6, DOY 63.5-66.5), when air masses from the Indian Subcontinent arrived at the ship, three types of particle fractions were detected (less-hygroscopic, more-hygroscopic, and nearly hydrophobic). In this case, particles with growth factors smaller than 1.3 were labeled as nearly hydrophobic particles. For this time period, the highest light absorption coefficient as well as the highest EC concentration were measured. The nearly hydrophobic particle group had growth factors between 1.15 and 1.3. 
$\Delta \mathrm{gf}($ more-hygr.)

af(less-hygr.)

- gf(nearly-hydr.)

$\Delta \mathrm{nf}$ (more-hygr.)

$\square \mathrm{nf}$ (less-hygr.)

O nf(nearly-hydr.)

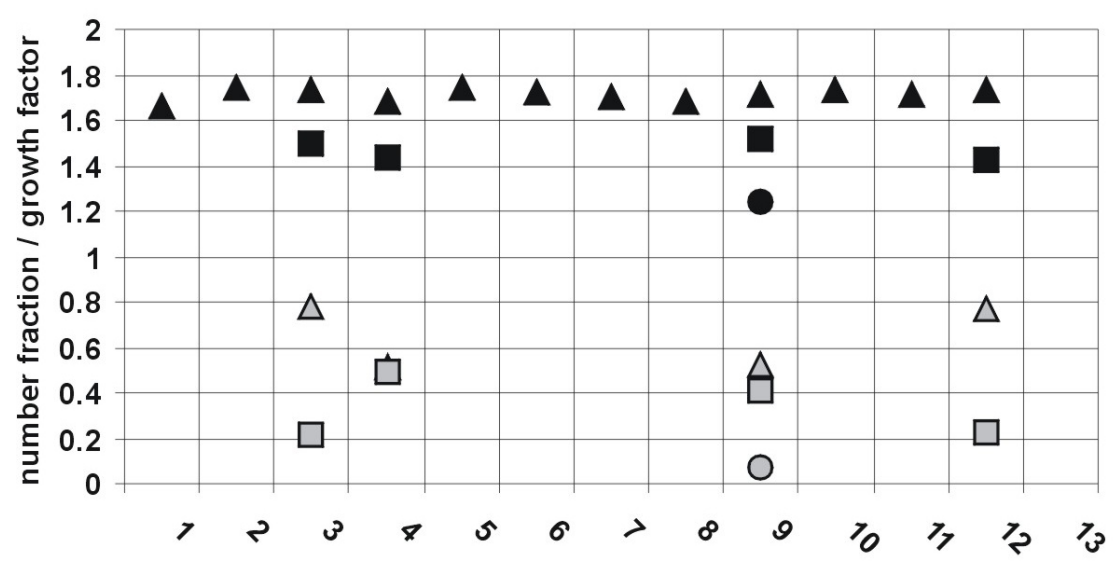

(a) $\mathrm{Dp}=50 \mathrm{~nm}$

\section{$\Delta \mathrm{gf}$ (more-hygr.) \\ gf(more-hygr.) \\ - gf(nearly-hydr.) \\ $\Delta \mathrm{nf}$ (more-hygr.) \\ $\square$ nf(less-hygr.) \\ O nf(nearly-hydr.)}

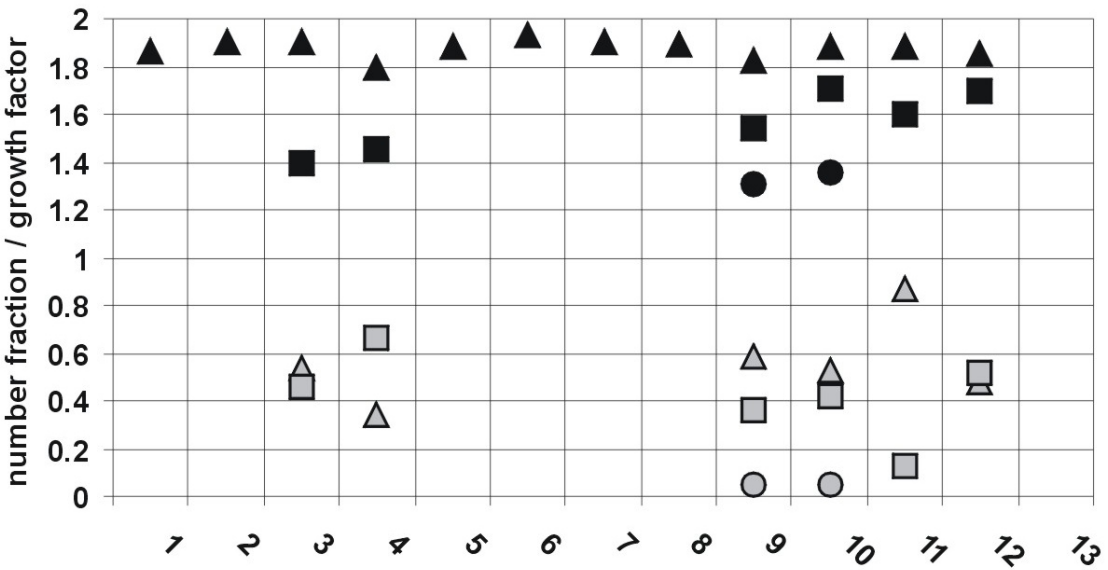

(b) $\mathrm{Dp}=150 \mathrm{~nm}$

time period

A gf(more-hygr.)
gf(more-hygr.)
gf(nearly-hydr.)
$\Delta$ nf(more-hygr.)
$\square$ nf(less-hygr.)
O nf(nearly-hydr.)

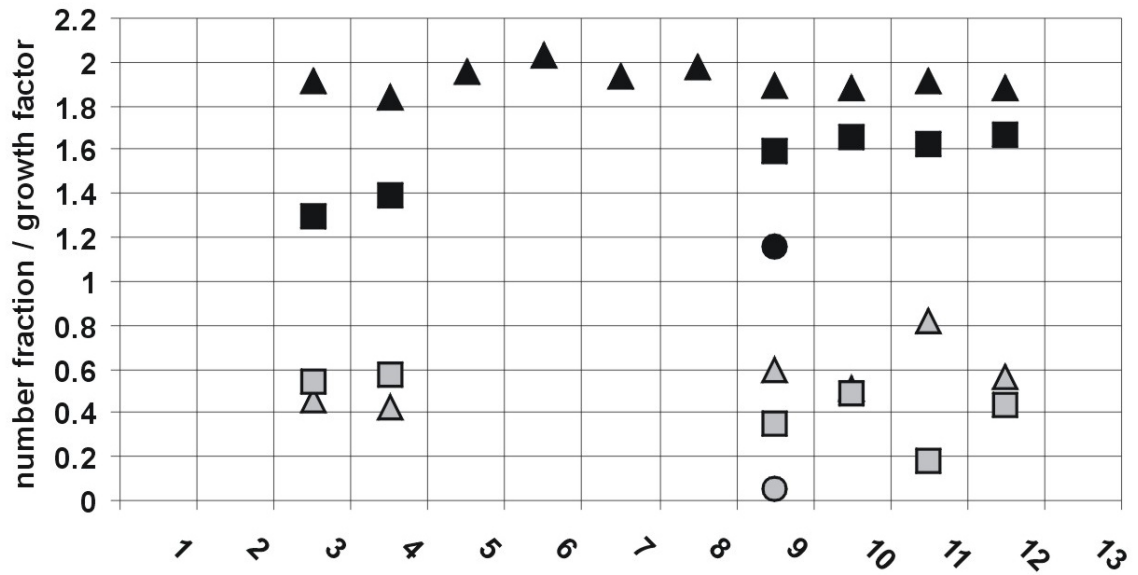

(c) $\mathrm{Dp}=250 \mathrm{~nm}$

time period

Fig. 6. Averaged hygroscopic growth factors measured at $90 \% \mathrm{RH}$ and number fractions of less-hygroscopic particles for particles with dry particle diameter $D p$ of (a) $50 \mathrm{~nm}$, (b) $150 \mathrm{~nm}$, and (c) $250 \mathrm{~nm}$ measured during Aerosols99 and INDOEX. 
Table 2. Average growth factors of more- and less-hygroscopic particle groups and number fraction of less-hygroscopic particle group of particles with an initial dry size of 50nm for observed air masses with different origin during Aerosols 99

\begin{tabular}{|c|c|c|c|c|c|}
\hline $\begin{array}{l}\text { Time } \\
\text { period }\end{array}$ & $\begin{array}{l}\text { Relative humidity, } \\
\quad R H[\%]\end{array}$ & $\begin{array}{l}\text { Hygroscopic growth factor } \\
\text { (more-hygroscopic fraction) }+/-\mathrm{sd}\end{array}$ & $\begin{array}{l}\text { Hygroscopic growth factor } \\
\text { (less-hygroscopic fraction) }+/-\mathrm{sd}\end{array}$ & $\begin{array}{l}\text { Number of observations } \\
\text { (more/less-hygroscopic fraction) }\end{array}$ & $\begin{array}{c}\text { Number fraction of less-hygroscopic } \\
\text { particles }+1-\text { sd }\end{array}$ \\
\hline \multirow[t]{4}{*}{1} & 90 & $1.66+/-0.03$ & - & $14 /-$ & - \\
\hline & 75 & $1.35+/-0.01$ & - & $16 /-$ & - \\
\hline & 55 & $1.19+/-0.01$ & - & $12 /-$ & - \\
\hline & 30 & $1.08+/-0.01$ & - & $15 /-$ & - \\
\hline \multirow[t]{4}{*}{2} & 90 & $1.74+/-0.04$ & - & $10 /-$ & - \\
\hline & 75 & 1.36 & - & $1 /-$ & - \\
\hline & 55 & $1.20+/-0.01$ & - & $2 /-$ & - \\
\hline & 30 & $1.08+/-0.01$ & - & $2 /-$ & - \\
\hline \multirow[t]{4}{*}{3} & 90 & $1.73+/-0.03$ & $1.50+/-0.08$ & $5 / 5$ & $0.22+/-0.08$ \\
\hline & 75 & $1.37+/-0.01$ & $1.20+/-0.02$ & $7 / 6$ & $0.19+/-0.08$ \\
\hline & 55 & $1.17+/-0.01$ & - & $6 /-$ & - \\
\hline & 30 & $1.07+/-0.01$ & - & $6 /-$ & - \\
\hline \multirow[t]{4}{*}{4} & 90 & $1.68+/-0.05$ & $1.44+/-0.07$ & $14 / 9$ & $0.49+/-0.17$ \\
\hline & 75 & $1.32+/-0.02$ & 1.19 & $4 / 1$ & 0.19 \\
\hline & 55 & $1.15+/-0.02$ & - & $4 /-$ & - \\
\hline & 30 & $1.06+/-0.02$ & - & $2 /-$ & - \\
\hline \multirow[t]{4}{*}{5} & 90 & $1.74+/-0.02$ & - & $15 /-$ & - \\
\hline & 75 & $1.39+/-0.02$ & - & $11 /-$ & - \\
\hline & 55 & $1.22+/-0.02$ & - & $10 /-$ & - \\
\hline & 30 & $1.11+/-0.02$ & - & $12 /-$ & - \\
\hline \multirow[t]{4}{*}{6} & 90 & $1.72+/-0.05$ & - & $28 /-$ & - \\
\hline & 75 & $1.40+/-0.03$ & - & 9/- & - \\
\hline & 55 & $1.24+/-0.01$ & - & 9/- & - \\
\hline & 30 & $1.12+/-0.01$ & - & 9/- & - \\
\hline \multirow[t]{4}{*}{7} & 90 & $1.70+/-0.03$ & - & 9/- & - \\
\hline & 75 & $1.37+/-0.03$ & - & $3 /-$ & - \\
\hline & 55 & $1.22+/-0.01$ & - & $4 /-$ & - \\
\hline & 30 & $1.11+/-0.01$ & - & $3 /-$ & - \\
\hline
\end{tabular}

\section{Number fractions}

The average number fraction of less-hygroscopic particles was about $22 \%(50 \mathrm{~nm})$ and $46 \%(150 \mathrm{~nm})$ for time period 3 (mixed: African dust and biomass burning in the ITZC, Aerosols99, DOY 25-27) and increased to approximately $49 \%(50 \mathrm{~nm})$ and $66 \%(150 \mathrm{~nm})$ for time period 4 (biomass burning in the ITZC, Aerosols99, DOY 27-29.8). The higher fraction in time period 4 corresponds with a much higher EC concentration in time period $4\left(0.43 \mu \mathrm{g} / \mathrm{m}^{3}\right)$ than in time period $3\left(0.30 \mu \mathrm{g} / \mathrm{m}^{3}\right)$ for sub- $\mu \mathrm{m}$ particles, although the total aerosol mass decreased. This correspondence indicates that less-hygroscopic particles were mainly composed of EC.

The number fraction of less-hygroscopic particles for time period 9 (INDOEX, DOY 63.5-66.5) averaged between 35 and $41 \%$ depending on dry particle size, the number fraction of nearly hydrophobic particles averaged between 5 to $7 \%$. In this time period, these particles were from Indian Subcontinent air masses arriving at the ship. The back-trajectory analysis shows a travel time of 12 to 36 hours for these air masses to reach the ship from the continent. These high number fractions correspond to the highest measured EC-concentration $\left(1.64 \mu \mathrm{g} / \mathrm{m}^{3}\right)$ during the cruise. As high number fractions were also detected during other continentally polluted time periods during INDOEX, only a few observations of lesshygroscopic particles were made during these time periods. Time periods 10, 12, and 13 show travel times of several days for the air masses between the ship and the continent and thus the occurrence of less-hygroscopic particles was more infrequent, because the particles probably changed their composition by aging (cloud processing, condensation from the gas phase, accumulation).

Overall, continentally influenced marine air masses could be identified during both field studies by the occurrence of less-hygroscopic and nearly hydrophobic groups of aerosol particles. A strong continental influence was indicated to increased concentrations of sub- $\mu \mathrm{m}$ elemental carbon related to high values of number fractions of less-hygroscopic particles. 
Table 3. Average growth factors of more- and less-hygroscopic particle groups and number fraction of less-hygroscopic particle group of particles with an initial dry size of $150 \mathrm{~nm}$ for observed air masses with different origin during Aerosols 99

\begin{tabular}{|c|c|c|c|c|c|}
\hline $\begin{array}{l}\text { Time } \\
\text { period }\end{array}$ & $\begin{array}{l}\text { Relative humidity, } \\
\text { RH[\%] }\end{array}$ & $\begin{array}{l}\text { Hygroscopic growth factor } \\
\text { (more-hygroscopic fraction) }+/- \text { sd }\end{array}$ & $\begin{array}{c}\text { Hygroscopic growth factor } \\
\text { (less-hygroscopic fraction) }+1-\text { sd }\end{array}$ & $\begin{array}{c}\text { Number of observations } \\
\text { (more/less-hygroscopic fraction) }\end{array}$ & $\begin{array}{l}\text { Number fraction of less-hygroscopic } \\
\text { particles }+/- \text { sd }\end{array}$ \\
\hline \multirow[t]{4}{*}{1} & 90 & $1.86+/-0.05$ & - & $11 /-$ & - \\
\hline & 75 & $1.48+/-0.01$ & - & $11 /-$ & - \\
\hline & 55 & $1.30+/-0.01$ & - & $12 /-$ & - \\
\hline & 30 & $1.15+/-0.01$ & - & 19/- & - \\
\hline \multirow[t]{4}{*}{2} & 90 & $1.90+/-0.03$ & - & 9/- & - \\
\hline & 75 & 1.47 & - & $1 /-$ & - \\
\hline & 55 & $1.26+/-0.03$ & - & $2 /-$ & - \\
\hline & 30 & $1.13+/-0.02$ & - & $2 /-$ & - \\
\hline \multirow[t]{4}{*}{3} & 90 & $1.90+/-0.03$ & $1.47+/-0.13$ & $5 / 5$ & $0.46+/-0.19$ \\
\hline & 75 & $1.44+/-0.02$ & $1.17+/-0.03$ & $6 / 5$ & $0.46+/-0.18$ \\
\hline & 55 & $1.18+/-0.04$ & - & $4 /-$ & - \\
\hline & 30 & $1.10+/-0.01$ & - & $6 /-$ & - \\
\hline \multirow[t]{4}{*}{4} & 90 & $1.80+/-0.05$ & $1.45+/-0.06$ & $10 / 10$ & $0.66+/-0.09$ \\
\hline & 75 & 1.25 & - & $1 /-$ & - \\
\hline & 55 & $1.14+/-0.01$ & - & $4 /-$ & - \\
\hline & 30 & $1.08+/-0.01$ & - & $3 /-$ & - \\
\hline \multirow[t]{4}{*}{5} & 90 & $1.88+/-0.03$ & - & $15 /-$ & - \\
\hline & 75 & $1.48+/-0.02$ & - & $11 /-$ & - \\
\hline & 55 & $1.29+/-0.02$ & - & $11 /-$ & - \\
\hline & 30 & $1.17+/-0.03$ & - & $12 /-$ & - \\
\hline \multirow[t]{4}{*}{6} & 90 & $1.93+/-0.03$ & - & $24 /-$ & - \\
\hline & 75 & $1.51+/-0.03$ & - & $10 /-$ & - \\
\hline & 55 & $1.33+/-0.01$ & - & $8 /-$ & - \\
\hline & 30 & $1.19+/-0.01$ & - & 9/- & - \\
\hline \multirow[t]{4}{*}{7} & 90 & $1.90+/-0.05$ & - & 9/- & - \\
\hline & 75 & $1.50+/-0.04$ & - & $4 /-$ & - \\
\hline & 55 & $1.31+/-0.01$ & - & $4 /-$ & - \\
\hline & 30 & $1.18+/-0.01$ & - & $4 /-$ & - \\
\hline
\end{tabular}

\subsubsection{Growth factors of different aerosol types measured at $75 \% R H$}

For the hygroscopic growth factors measured at $75 \% \mathrm{RH}$, the trends are similar to those seen for the factors measured at $90 \% R H$ (Fig. 6). Average growth factors of morehygroscopic particles were between 1.32 and $1.40(50 \mathrm{~nm})$, between 1.25 and $1.51(150 \mathrm{~nm})$, and between 1.39 and $1.54(250 \mathrm{~nm})$. In contrast, less-hygroscopic particles measured at $75 \% R H$ ranged between 1.17 and $1.20(50 \mathrm{~nm})$, 1.17 and $1.20(150 \mathrm{~nm})$, and 1.12 and $1.29(250 \mathrm{~nm}) \mathrm{de}-$ pending on the type of air mass. Nearly hydrophobic particles and less-hygroscopic particles could not be separated in two modes at $75 \% R H$. The growth factors of the morehygroscopic particle fraction correspond to the high growth factors measured at $90 \% R H$ for this particle fraction. This correspondence implies that these particles were composed of high amounts of hygroscopically active material, as discussed earlier for the chemical inorganic composition that showed ammonium and sulfate dominating the molar distribution. The less-hygroscopic particles measured at $75 \%$
$R H$ occurred only when continentally influenced air masses were encountered, corresponding to increased mass concentrations of EC (Table 1).

4.5.3 Growth factors of different aerosol types measured at $55 \%$ and at $30 \% R H$

For the hygroscopicity measurements done at 30 and $55 \%$ $R H$, the hygroscopic growth distribution appeared in one mode, hence less-hygroscopic and more-hygroscopic particles could not be distinguished. Figure 7 shows the hygroscopic growth factors measured at $55 \% \mathrm{RH}$.

During Aerosols99, a remarkable decrease in hygroscopic growth at 55\% RH occurred for continentally influenced air masses and for all three particle sizes (time periods 2-4, Figs. 7a, b and c, DOY 23-29.8). For Aitken mode particles $(D p=50 \mathrm{~nm}$, Fig. 7a), the average growth factor for the marine air masses ranged from 1.19 to 1.24 , whereas that for the continentally influenced air masses ranged from 1.15 to 1.20. For accumulation mode particles ( $D p=150$ and $250 \mathrm{~nm}$ ), this decrease in hygroscopic growth was greater (Figs. $7 b$ and c). 


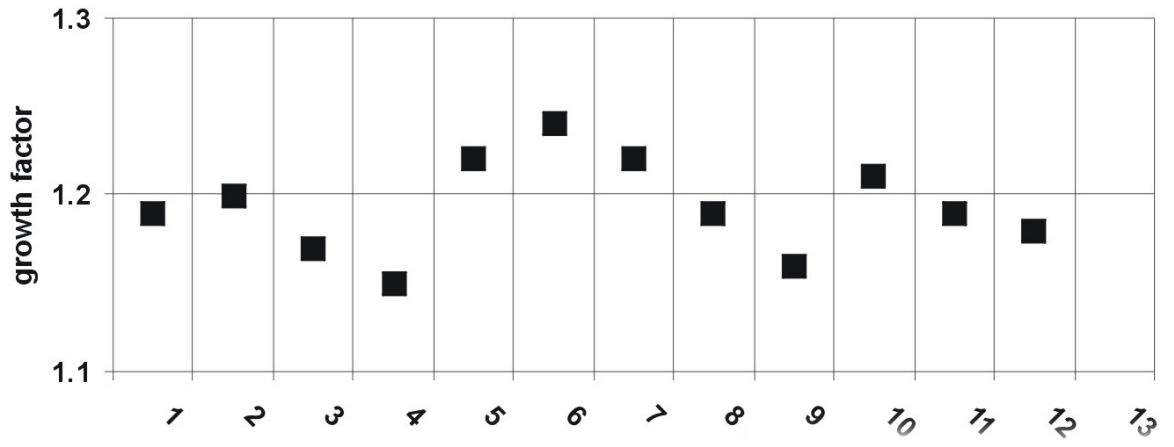

(a) $\mathrm{Dp}=50 \mathrm{~nm}$

time period

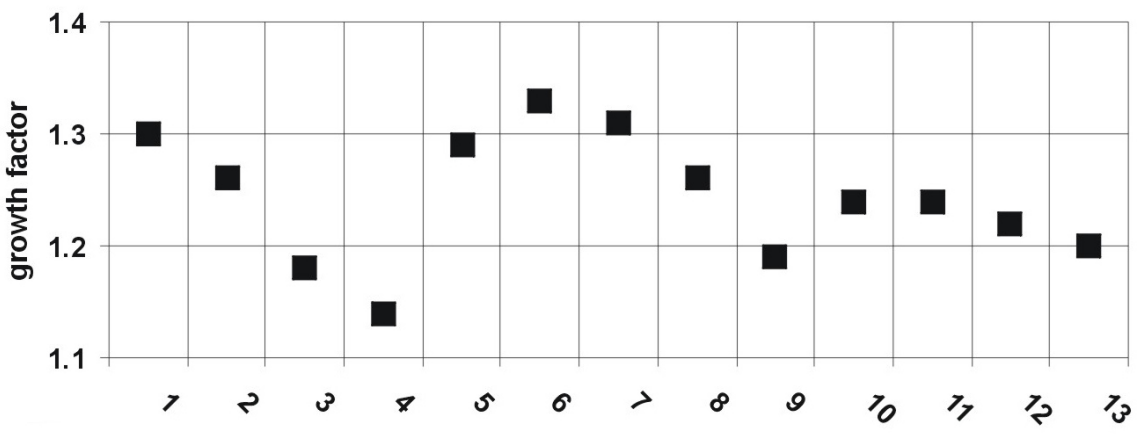

(b) $\mathrm{Dp}=150 \mathrm{~nm}$

time period

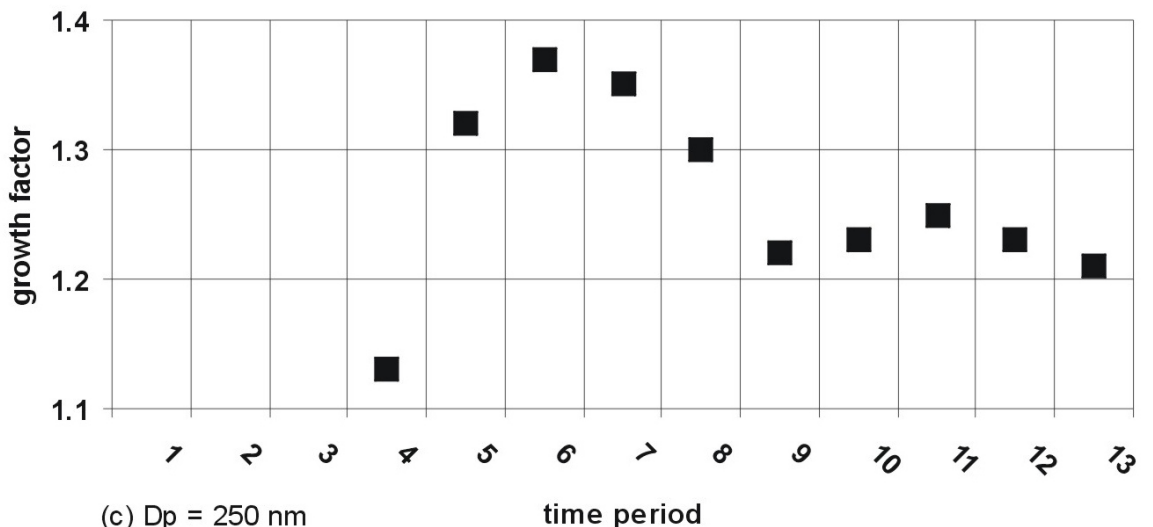

Fig. 7. Averaged hygroscopic growth factors measured at $55 \% \mathrm{RH}$ for particles with dry particle diameter $D p$ of (a) $50 \mathrm{~nm}$, (b) $150 \mathrm{~nm}$, and (c) $250 \mathrm{~nm}$ measured during Aerosols 99 and INDOEX.

A reduction in hygroscopic growth for continentally influenced air masses also occurred at $30 \% \mathrm{RH}$. Although particles generally absorb only small amounts of water at this low $R H$, the difference in hygroscopic growth was evident between clean marine air masses and continentally influenced air masses (Table 1/Fig. 7).
One reason for this behavior might be the very complex chemical composition during these continentally influenced time periods. Besides ammonium and sulfate also potassium and calcium was found in these determined size ranges. The decrease in $\mathrm{RH}$ from $90 \%$ to $55 \%$ might cause recrystallization for some compounds in the particle that are at $90 \%$ 
Table 4. Average growth factors of more- and less-hygroscopic particle groups and number fraction of less-hygroscopic particle group of particles with an initial dry size of 250nm for observed air masses with different origin during Aerosols 99

\begin{tabular}{|c|c|c|c|c|c|}
\hline $\begin{array}{l}\text { Time } \\
\text { period }\end{array}$ & $\begin{array}{l}\text { Relative humidity, } \\
\qquad R H[\%]\end{array}$ & $\begin{array}{l}\text { Hygroscopic growth factor } \\
\text { (more-hygroscopic fraction) }+/-\mathrm{sd}\end{array}$ & $\begin{array}{l}\text { Hygroscopic growth factor } \\
\text { (less-hygroscopic fraction) }+/- \text { sd }\end{array}$ & $\begin{array}{c}\text { Number of observations } \\
\text { (more/less-hygroscopic fraction) }\end{array}$ & $\begin{array}{l}\text { Number fraction of less-hygroscopic } \\
\text { particles }+/- \text { sd }\end{array}$ \\
\hline \multirow[t]{4}{*}{1} & 90 & - & - & - & - \\
\hline & 75 & - & - & - & - \\
\hline & 55 & - & - & - & - \\
\hline & 30 & - & - & - & - \\
\hline \multirow[t]{4}{*}{2} & 90 & - & - & - & - \\
\hline & 75 & - & - & - & - \\
\hline & 55 & - & - & - & - \\
\hline & 30 & - & - & - & - \\
\hline \multirow[t]{4}{*}{3} & 90 & $1.91+/-0.03$ & $1.30+/-0.03$ & $9 / 9$ & $0.54+/-0.01$ \\
\hline & 75 & $1.41+/-0.06$ & $1.12+/-0.01$ & $4 / 4$ & $0.49+/-0.15$ \\
\hline & 55 & - & - & - & - \\
\hline & 30 & $1.11+/-0.01$ & - & 6 & - \\
\hline \multirow[t]{4}{*}{4} & 90 & $1.84+/-0.09$ & $1.39+/-0.08$ & $12 / 12$ & $0.57+/-0.09$ \\
\hline & 75 & - & - & - & - \\
\hline & 55 & $1.13+/-0.01$ & - & 3 & - \\
\hline & 30 & $1.09+/-0.01$ & - & 4 & - \\
\hline \multirow[t]{4}{*}{5} & 90 & $1.96+/-0.04$ & - & $16 /-$ & - \\
\hline & 75 & $1.52+/-0.02$ & - & $11 /-$ & - \\
\hline & 55 & $1.32+/-0.03$ & - & 11 & - \\
\hline & 30 & $1.17+/-0.03$ & - & 10 & - \\
\hline \multirow[t]{4}{*}{6} & 90 & $2.03+1-0.02$ & - & $2 /-$ & - \\
\hline & 75 & $1.54+/-0.01$ & - & $2 /-$ & - \\
\hline & 55 & 1.37 & - & 1 & - \\
\hline & 30 & $1.14+/-0.03$ & - & 4 & - \\
\hline \multirow[t]{4}{*}{7} & 90 & $1.93+/-0.09$ & - & $8 /-$ & - \\
\hline & 75 & $1.54+/-0.05$ & - & $4 /-$ & - \\
\hline & 55 & $1.35+/-0.01$ & - & 3 & - \\
\hline & 30 & $1.20+/-0.01$ & - & 4 & - \\
\hline
\end{tabular}

$R H$ completely water soluble. Tang and Munkelwitz found a very difficult deliquescence and recrystallization behavior for mixed salt particles (1993).

During INDOEX, a decrease in hygroscopic growth at $55 \% R H$ occurred between time period 8 (Southern Hemisphere portion of the Marine Indian Ocean, Fig. 7, DOY 5456.6) to time period 9 (Indian Subcontinent and directly to the ship, Fig. 7, DOY 63.5-66.5). This decrease was particularly evident for the accumulation mode particles. However, variations in hygroscopic growth during INDOEX at $30 \%$ and $55 \% R H$ between different air masses were small, and were only noticeable for the change in air mass between time period 8 (Southern Hemisphere portion of the Marine Indian Ocean) and time period 9 (Indian Subcontinent and directly to the ship) and for particles with initial dry sizes of 150 and $250 \mathrm{~nm}$.

4.5.4 Parameterization of hygroscopic growth of morehygroscopic particles

Information on hygroscopic growth of aerosol particles is critical in determining the influence of such particles on the earth's radiative budget. The increase in particle size due to the uptake of water is an important parameter for characterizing aerosol particles at ambient conditions. Models dealing with the impact of aerosol particles on the radiative balance need this information to calculate size distributions at ambient $R H$ in the highly varying humidity field of the troposphere. Based on a parameterization by Swietlicki et al. (1999), we derived a parameterization of hygroscopic growth from the hygroscopic growth data measured at 90 , 75 , 55, and $30 \% R H$ for all measured particle sizes. Therefore, a simple function with two fit parameters (Eq. 3) has been adapted to the data obtained during Aerosols99 and INDOEX:

$g f(R H)=A \times(1-R H)^{\gamma}$.

This parameterization is only valid for $30 \% \leq R H \leq 90 \%$. In this equation, $R H$ is not a percentage but rather a number between 0 and 1 , defined as the ratio between the actual water vapor pressure and the saturation water vapor pressure. The fit parameters, $\mathrm{A}$ and $\gamma$, were derived for the averaged growth factors of the more-hygroscopic particle fractions at $90 \%$ and at $75 \% R H$ and for the single hygroscopic growth 


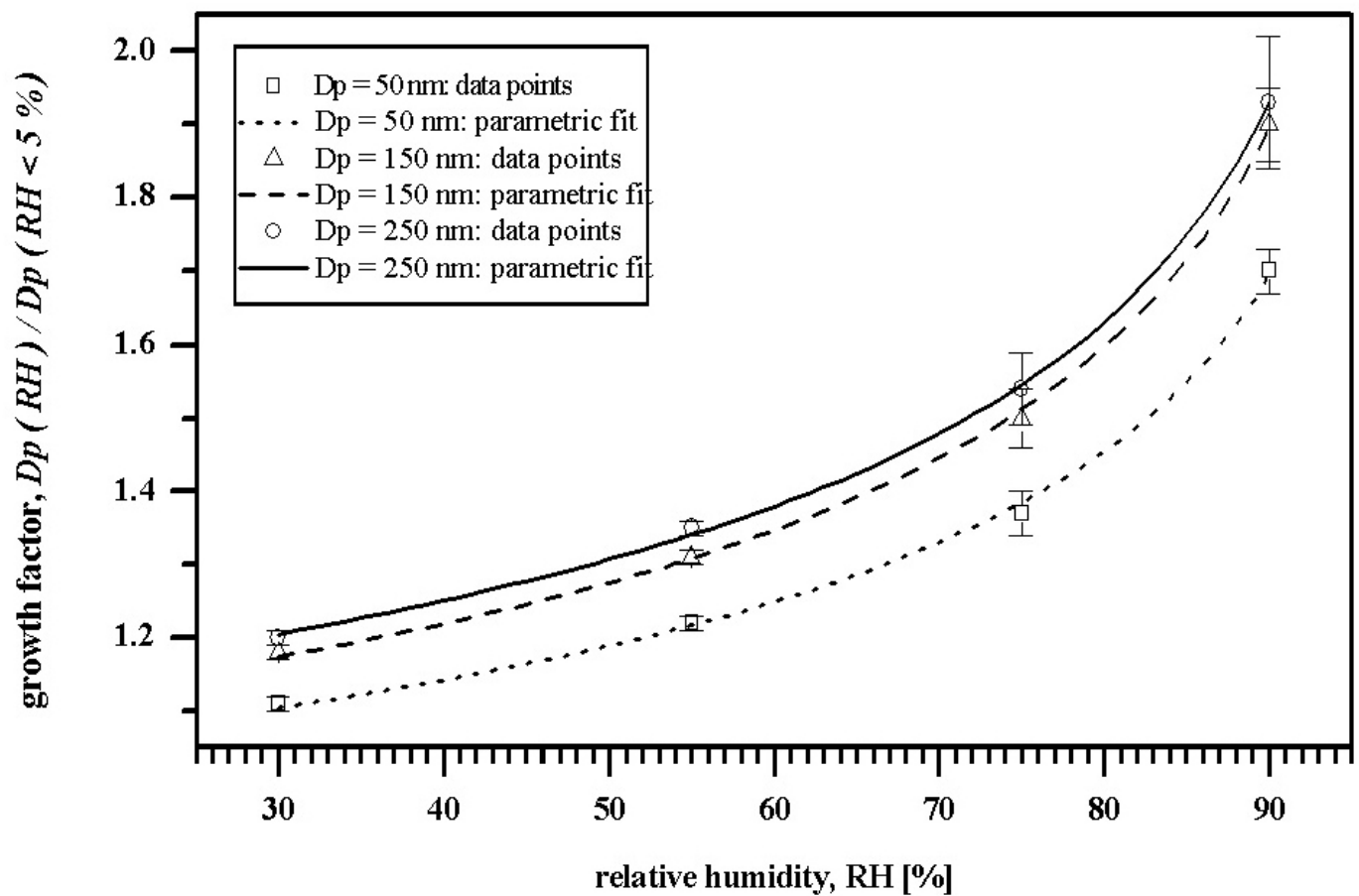

Fig. 8. Parametric fit of hygroscopic growth factors (more-hygroscopic particle fraction) measured at $30,55,75$, and $90 \% R H$ for particles with dry particle diameter $D p$ of (a) $50 \mathrm{~nm}$, (b) $150 \mathrm{~nm}$, and (c) $250 \mathrm{~nm}$ measured for a southern Indian Ocean marine air mass during Aerosols99. The error bars display the standard deviation of the averaged measured values.

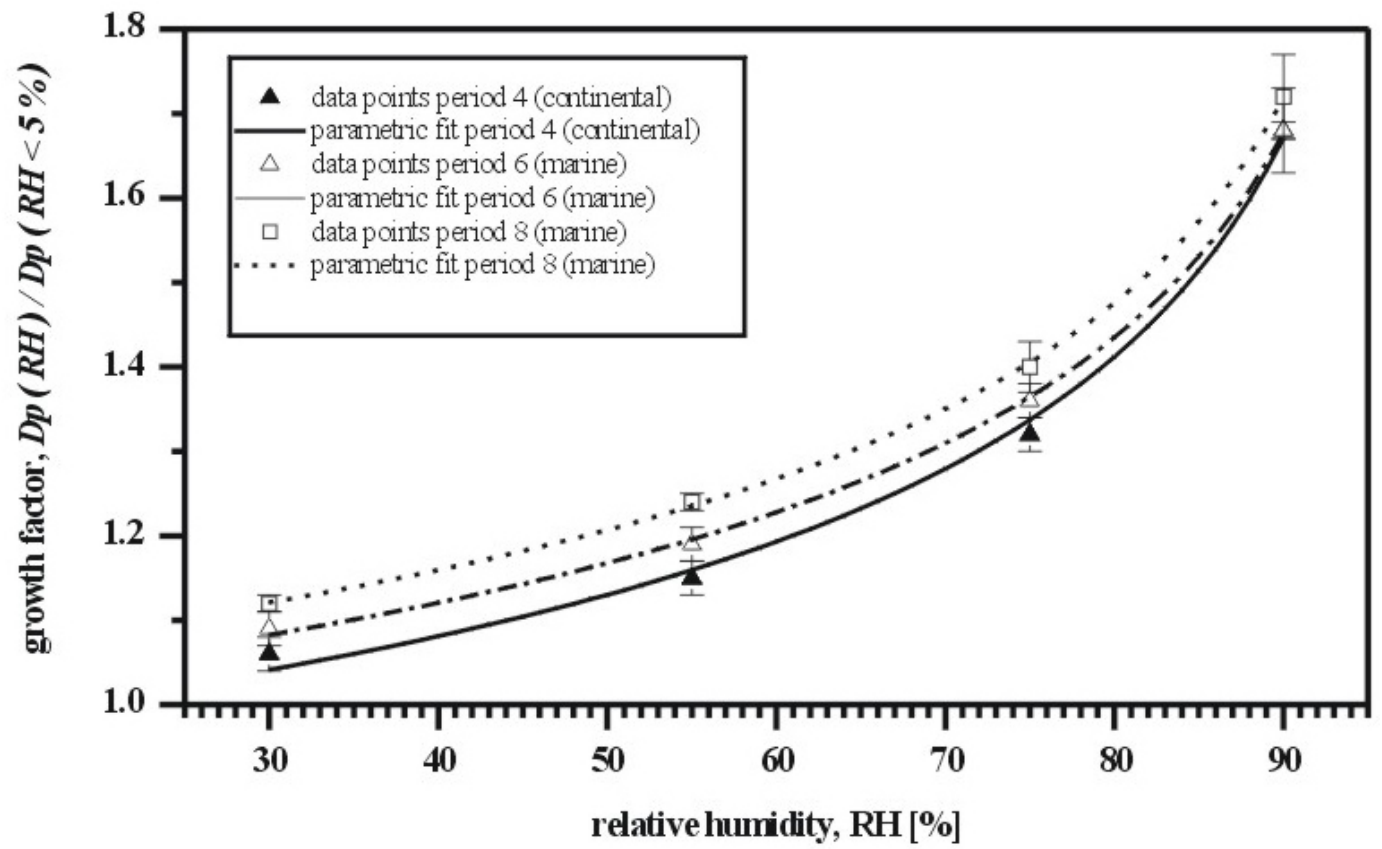

Fig. 9. Parametric fit of hygroscopic growth factors (more-hygroscopic particle fraction) measured at 30, 55, 75 and $90 \% \mathrm{RH}$ for particles with dry particle diameter $D p=50 \mathrm{~nm}$ measured for different air masses during Aerosols99. The error bars display the standard deviation of the averaged measured values. 
Table 5. Fit parameters derived using Eq. (3) for hygroscopic growth factors at 30, 55, 75, and 90\% $R H$ during Aerosols 99

\begin{tabular}{llll}
\hline Time period & Dry particle diameter, $D p=50 \mathrm{~nm}$ & Dry particle diameter, $D p=150 \mathrm{~nm}$ & Dry particle diameter, $D p=250 \mathrm{~nm}$ \\
\hline 1 & $\mathrm{~A}=0.9966+/-0.0028$ & $\mathrm{~A}=1.0600+/-0.0086$ & - \\
& $\gamma=-0.2212+/-0.0017$ & $\gamma=-0.2440+/-0.0049$ & - \\
2 & $\mathrm{~A}=0.9812+/-0.0141$ & $\mathrm{~A}=1.0182+/-0.0081$ & - \\
& $\gamma=-0.2467+/-0.0087$ & $\gamma=-0.2699+/-0.0047$ & - \\
5 & $\mathrm{~A}=1.1014+/-0.0084$ & $\mathrm{~A}=1.0614+/-0.0109$ & $\mathrm{~A}=1.0624+/-0.0092$ \\
& $\gamma=-0.2333+/-0.0050$ & $\gamma=-0.2468+/-0.0062$ & $\gamma=-0.2649+/-0.0052$ \\
6 & $\mathrm{~A}=1.0365+/-0.0043$ & $\mathrm{~A}=1.0837+/-0.0134$ & $\mathrm{~A}=1.0544+/-0.0324$ \\
& $\gamma=-0.2196+/-0.0025$ & $\gamma=-0.2490+/-0.0075$ & $\gamma=-0.2840+/-0.0182$ \\
7 & $\mathrm{~A}=1.0207+/-0.0100$ & $\mathrm{~A}=1.0751+/-0.0084$ & $\mathrm{~A}=1.1051+/-0.0067$ \\
& $\gamma=-0.2201+/-0.0060$ & $\gamma=-0.2462+/-0.0047$ & $\gamma=-0.2420+/-0.0037$ \\
\hline
\end{tabular}

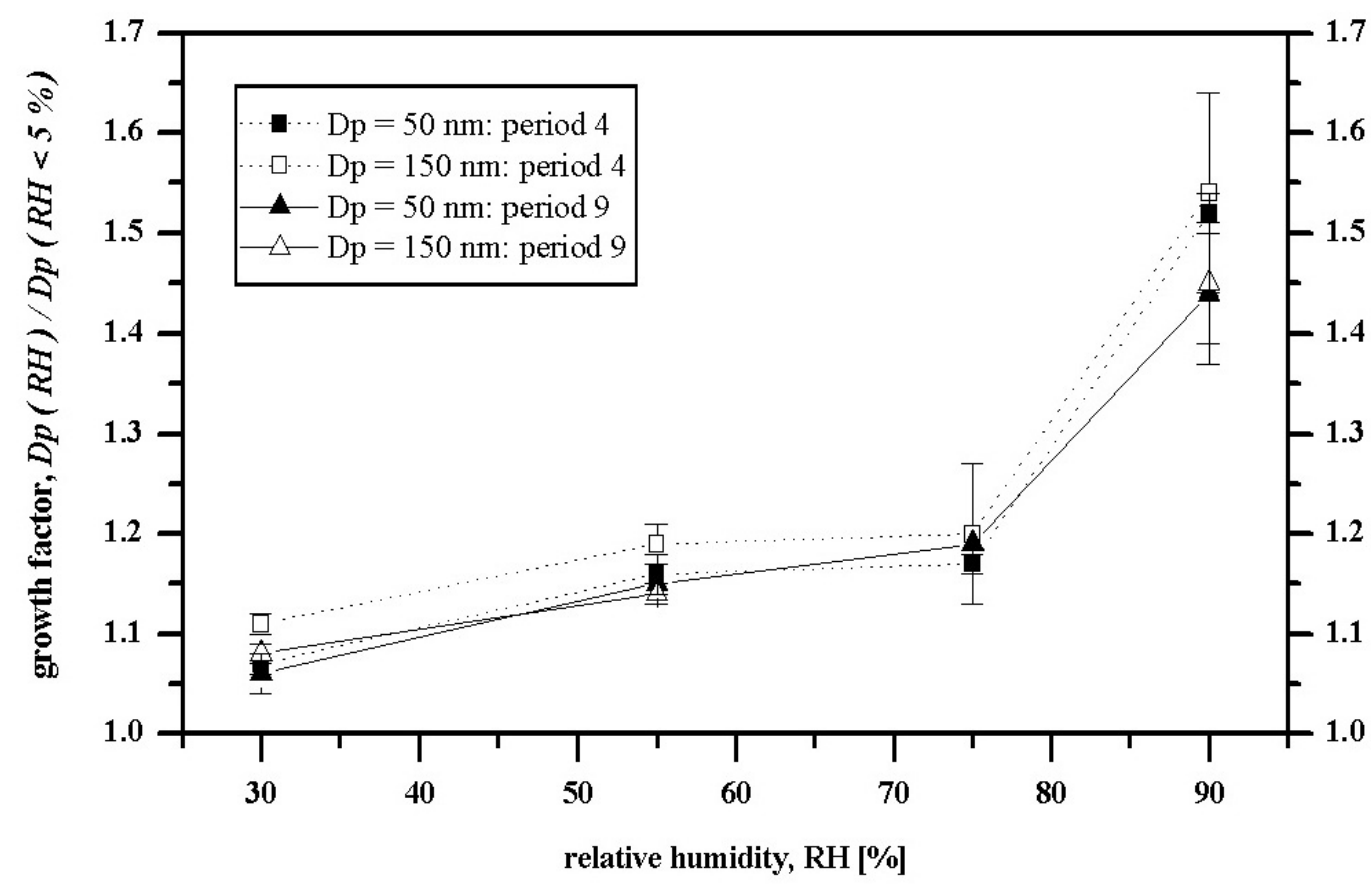

Fig. 10. Hygroscopic growth factors of the less-hygroscopic particles with an initial dry size of 50 and $150 \mathrm{~nm}$ found during different time periods. The error bars display the standard deviation of the averaged measured values.

mode found at $55 \%$ and at $30 \% R H$. Figure 8 shows the parametric fits for dry particle sizes of 50,150 , and $250 \mathrm{~nm}$ for the Southern Indian Ocean marine air mass encountered in time period 7 during Aerosols99.

Generally, the calculated and measured hygroscopic growth factors increased with increasing dry particle size. The similarity in the shape of these curves shows that particles exhibited similar behavior in hygroscopic growth, although the growth itself differed and this difference was greater between the $50 \mathrm{~nm}$ and $150 \mathrm{~nm}$ particles than between the $150 \mathrm{~nm}$ and $250 \mathrm{~nm}$ particles. One reason for this difference is the Kelvin effect, which mainly affects particles smaller than $100 \mathrm{~nm}$ in diameter. Based on a model by Tang and Munkelwitz (1994), a pure ammonium sul- fate particle with a dry size of $50 \mathrm{~nm}$ shows a growth factor of 1.65 at $90 \% R H$ and particles of dry sizes of 150 and $250 \mathrm{~nm}$ grow up to values of 1.71 and 1.72 . This indicates that differences in growth between Aitken and accumulation mode particles can not only be explained by this effect for the given time period. Another reason might be that during this time period the accumulation mode particles (impactor stage two: $184 \mathrm{~nm}<D_{a e}<308 \mathrm{~nm}$ ) also included sea salt as discussed in the chemistry section. This sea salt might lead to an increase in hygroscopic growth, especially at high $R H$. Thus, the difference in hygroscopic growth between $150 \mathrm{~nm}$ and $250 \mathrm{~nm}$ particles is small for this given air mass (time period 7, Southern Indian Ocean marine air mass, Aerosols99). This behavior was generally observed 
Table 6. Average growth factors of more-hygroscopic, less-hygroscopic, and nearly hydrophobic particle groups and number fraction of less-hygroscopic particle group of particles with an initial dry size of 50nm for observed air masses with different origin during INDOEX

\begin{tabular}{|c|c|c|c|c|c|c|c|}
\hline $\begin{array}{l}\text { Time } \\
\text { period }\end{array}$ & $\begin{array}{l}\text { Relative } \\
\text { humidity, } \\
\text { RH [\%] }\end{array}$ & $\begin{array}{c}\text { Hygroscopic growth factor } \\
\text { (more-hygroscopic fraction) } \\
+/- \text { sd }\end{array}$ & $\begin{array}{l}\text { Hygroscopic growth factor } \\
\text { (less-hygroscopic fraction) } \\
+/- \text { sd }\end{array}$ & $\begin{array}{c}\text { Hygroscopic growth factor } \\
\text { (nearly hydrophobic fraction) } \\
+/- \text { sd }\end{array}$ & $\begin{array}{l}\text { Number of observations } \\
\text { (more-hygroscopic/ } \\
\text { less-hygroscopic/ } \\
\text { nearly hydrophobic fraction) }\end{array}$ & $\begin{array}{l}\text { Number fraction of } \\
\text { less-hygroscopic } \\
\text { particles }+1-\text { sd }\end{array}$ & $\begin{array}{l}\text { Number fraction of } \\
\text { nearly hydrophobic } \\
\text { particles }+/- \text { sd }\end{array}$ \\
\hline \multirow[t]{4}{*}{8} & 90 & $1.68+/-0.01$ & - & - & $10 /-/-$ & - & - \\
\hline & 75 & $1.36+/-0.02$ & - & - & $5 /-1-$ & - & - \\
\hline & 55 & $1.19+/-0.02$ & - & - & $4 /-1-$ & - & - \\
\hline & 30 & $1.09+/-0.02$ & - & - & $7 /-1-$ & - & - \\
\hline \multirow[t]{4}{*}{9} & & $1.71+/-0.01$ & $1.52+/-0.02$ & $1.24+/-0.03$ & $7 / 7 / 2$ & $0.41+/-0.13$ & $0.07+/-0.03$ \\
\hline & 75 & $1.34+/-0.02$ & $1.17+/-0.01$ & - & $4 / 4 /-$ & $0.26+/-0.13$ & - \\
\hline & 55 & $1.16+/-0.02$ & - & - & $4 /-1-$ & - & - \\
\hline & 30 & $1.07+/-0.01$ & - & - & $4 /-1-$ & - & - \\
\hline \multirow[t]{4}{*}{10} & & $1.73+/-0.02$ & - & - & $42 /-1-$ & - & - \\
\hline & 75 & $1.37+/-0.02$ & - & - & $10 /-/-$ & - & - \\
\hline & 55 & $1.21+/-0.01$ & - & - & $10 /-\mid-$ & - & - \\
\hline & 30 & $1.10+/-0.01$ & - & - & $10 /-/-$ & - & - \\
\hline \multirow[t]{4}{*}{11} & & $1.71+/-0.03$ & - & - & $20 /-/-$ & - & - \\
\hline & 75 & $1.35+/-0.02$ & - & - & 8/-1- & - & - \\
\hline & 55 & $1.19+/-0.01$ & - & - & 9/-/- & - & - \\
\hline & 30 & $1.09+/-0.01$ & - & - & $3 /-1-$ & - & - \\
\hline \multirow[t]{4}{*}{12} & & $1.73+/-0.05$ & $1.43+/-0.19$ & - & 19/2/- & $0.23+/-0.22$ & - \\
\hline & 75 & $1.35+/-0.06$ & - & - & $5 /-1-$ & - & - \\
\hline & 55 & $1.18+/-0.01$ & - & - & $6 /-1-$ & - & - \\
\hline & 30 & $1.09+/-0.02$ & - & - & 8/-/- & - & - \\
\hline \multirow[t]{4}{*}{13} & & - & - & - & - & - & - \\
\hline & 75 & - & - & - & - & - & - \\
\hline & 55 & - & - & - & - & - & - \\
\hline & 30 & 1.07 & - & - & $1 /-/-$ & - & - \\
\hline
\end{tabular}

during both field experiments for the marine air masses, because Aitken mode particles principally are formed by different mechanisms in the marine boundary layer in contrast to accumulation mode particles.

Figure 9 shows a comparison of parametric fits for $50 \mathrm{~nm}$ particles (more-hygroscopic) for clean marine air masses in time period 6 (South Atlantic marine air mass, Aerosols99) and time period 8 (Marine Indian Ocean air mass, INDOEX), and for the continentally polluted air masses in time period 4 (biomass burning in the ITCZ, Aerosols99). At low $R H$ $(\leq 75 \%)$, the difference in hygroscopic growth between the two types of air masses was significant, whereas at high $\mathrm{RH}$ $(\geq 75 \%)$, the difference was small. These trends shown in Fig. 9 were independent of particle size. Indeed, these differences disappear with increasing $R H$. A possible reason for this effect of $R H$ could be that at high $R H$ the growth factors for more- and less-hygroscopic particles are observed as separate modes, whereas at low $R H$, these modes are no more resolved. This results in a common single mode growth factor which underestimates the more-hygroscopic growth factor, and overestimates the less-hygroscopic one. On the other hand a considerable shift in growth between period 6 and period 8 was observed. This shift can be explained by the slight difference in chemical composition for Aitken mode particles. Only time period 8 was influenced by small concentrations of sodium and chloride ions in this size range leading to higher growth factors in this time period in contrast to time period 6.

The parametric fits explain well the hygroscopic behavior for the clean marine air masses. For the polluted air masses, the parametric fits do not always match the experimental value and its standard deviation. The parameterization using Eq. (3) is a good tool for describing hygroscopic growth of aerosol particles in unpolluted air masses at various $R H$. The fit results using A and $\gamma$ as fit parameters for all marine time periods are listed in Tables 5 and 9 .

\subsubsection{Hygroscopic growth of less-hygroscopic particles}

Figure 10 shows the hygroscopic growth factors for the lesshygroscopic particles $(50 \mathrm{~nm}$ and $150 \mathrm{~nm})$ together with the single hygroscopic growth mode determined at $55 \%$ and at $30 \% R H$ during time period 4 (biomass burning in the ITCZ, Aerosols99) and 9 (Indian Subcontinent and directly to the ship, INDOEX). As was mentioned before, less- and morehygroscopic particles could not be separated at low $R H$ of 
Table 7. Average growth factors of more-hygroscopic, less-hygroscopic, and nearly hydrophobic particle groups and number fraction of less- hygroscopic particle group of particles with an initial dry size of 150nm for observed air masses with different origin during INDOEX

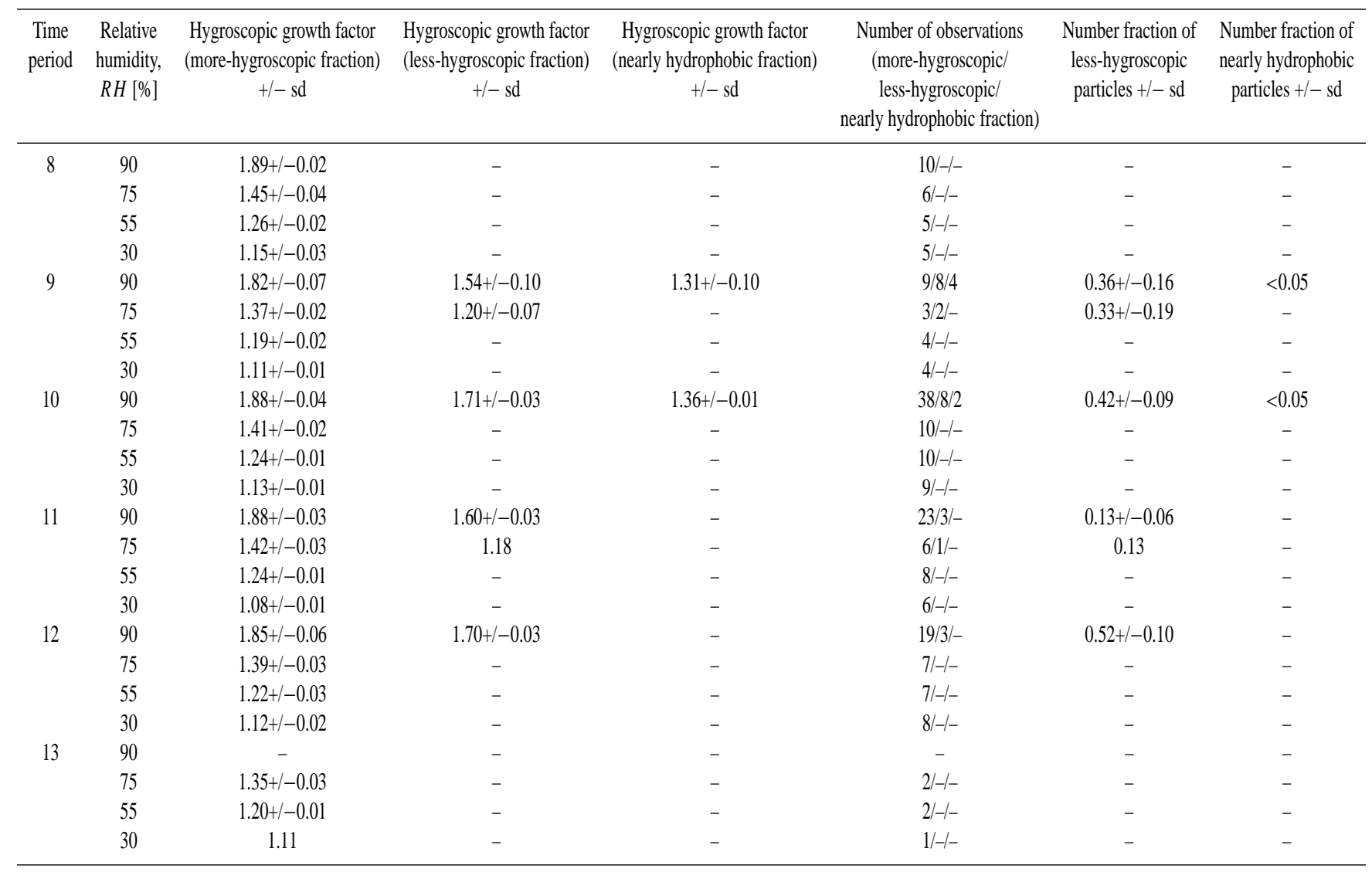

30 and $55 \%$, and thus only one growth factor was measured, leading to a small overestimation of the hygroscopic growth of these less-hygroscopic particles.

The hygroscopic growth for less-hygroscopic particles sharply increased from $75 \%$ to $90 \% R H$ (Fig. 10). This implies that the soluble fraction of the particles was not only inorganic salts. One reason for the sharp increase in hygroscopic growth from 75 to $90 \% R H$ of less-hygroscopic particles might be the complex chemical composition during time periods that were influenced by continental air masses. Beside having a high EC concentration mixed with soluble material, especially these less-hygroscopic particles might also contain organic material, which might influence the growth process. Organic material is known to show slight hygroscopicity and the knowledge about hygroscopic behavior of mixed particles is very limited up to now. The OC concentration was 0.28 (Aerosols99) and $0.81 \mu \mathrm{g} / \mathrm{m}^{3}$ (INDOEX) for sub- $\mu \mathrm{m}$ particles during the time periods 4 and 9 (Table 1). Saxena et al. (1995) found that for aged, nonurban air masses, organics contribute to the water uptake by inorganics, although the mechanism is not well understood.

\section{Summary and Conclusions}

Hygroscopic properties of aerosol particles were determined during two field studies, Aerosols99 (Atlantic Ocean) and INDOEX (Indian Ocean), on the U.S. Research Vessel Ronald H. Brown and were compared to concurrently measured chemical and optical properties of the particles. The Aerosols99 field study covered the Northern and Southern Hemisphere portions of the Atlantic Ocean, whereas the INDOEX field study covered both hemispheres of the Indian Ocean. During Aerosols99, marine air masses originating from the northern and southern Atlantic Ocean and air masses continentally influenced by Saharan mineral dust or biomass burning from western Africa were encountered. During INDOEX, clean marine air masses that had no land contact for five to six days originating in the Indian Ocean as well as polluted air masses having crossed the Indian Subcontinent or Arabia were encountered. The field studies involved a total of 13 consecutive time periods, ranging from one to six days each.

Hygroscopic properties were measured using an HTDMA system for particles with initial dry sizes $(D p)$ of 50,150 , and $250 \mathrm{~nm}$ and at relative humidities $(R H)$ of $30,55,75$, and 
Table 8. Average growth factors of more-hygroscopic, less-hygroscopic, and nearly hydrophobic particle groups and number fraction of less- hygroscopic particle group of particles with an initial dry size of 250nm for observed air masses with different origin during INDOEX

\begin{tabular}{|c|c|c|c|c|c|c|c|}
\hline $\begin{array}{l}\text { Time } \\
\text { period }\end{array}$ & $\begin{array}{l}\text { Relative } \\
\text { humidity, } \\
\text { RH [\%] }\end{array}$ & $\begin{array}{c}\text { Hygroscopic growth factor } \\
\text { (more-hygroscopic fraction) } \\
+/-s d\end{array}$ & $\begin{array}{c}\text { Hygroscopic growth factor } \\
\text { (less-hygroscopic fraction) } \\
+/- \text { sd }\end{array}$ & $\begin{array}{c}\text { Hygroscopic growth factor } \\
\text { (nearly hydrophobic fraction) } \\
+/- \text { sd }\end{array}$ & $\begin{array}{l}\text { Number of observations } \\
\text { (more-hygroscopic/ } \\
\text { less-hygroscopic/ } \\
\text { nearly hydrophobic fraction) }\end{array}$ & $\begin{array}{l}\text { Number fraction of } \\
\text { less-hygroscopic } \\
\text { particles +/- sd }\end{array}$ & $\begin{array}{c}\text { Number fraction of } \\
\text { nearly hydrophobic } \\
\text { particles }+/- \text { sd }\end{array}$ \\
\hline \multirow[t]{3}{*}{8} & 90 & $1.98+/-0.06$ & - & - & $4 /-/-$ & - & - \\
\hline & 75 & $1.48+/-0.04$ & - & - & $4 /-1-$ & - & - \\
\hline & 55 & $1.30+/-0.01$ & - & - & $2 /-1-$ & - & - \\
\hline \multirow{3}{*}{9} & 75 & $1.42+/-0.01$ & 1.29 & - & $2 / 1 /-$ & 0.42 & - \\
\hline & 55 & $1.22+/-0.02$ & - & - & $4 /-1-$ & - & - \\
\hline & 30 & $1.13+/-0.01$ & - & - & $4 /-1-$ & - & - \\
\hline \multirow[t]{2}{*}{10} & 90 & $1.88+/-0.05$ & $1.66+/-0.08$ & - & $34 / 11 /-$ & $0.49+/-0.22$ & - \\
\hline & 75 & $1.41+/-0.03$ & 1.26 & - & $7 / 1 /-$ & 0.25 & - \\
\hline \multirow{2}{*}{11} & 55 & $1.25+/-0.01$ & - & - & $7 /-1-$ & - & - \\
\hline & 30 & $1.13+/-0.01$ & - & - & $6 /-1-$ & - & - \\
\hline \multirow[t]{4}{*}{12} & 90 & $1.88+/-0.06$ & $1.67+/-0.04$ & - & $8 / 7 /-$ & $0.44+/-0.12$ & - \\
\hline & 75 & $1.40+/-0.01$ & 1.18 & - & $3 / 1 /-$ & 0.12 & - \\
\hline & 55 & $1.23+/-0.02$ & - & - & $6 /-1-$ & - & - \\
\hline & 30 & $1.13+/-0.02$ & - & - & $7 /-1-$ & - & - \\
\hline \multirow[t]{4}{*}{13} & 90 & - & - & - & - & - & - \\
\hline & 75 & 1.39 & - & - & $1 /-/-$ & - & - \\
\hline & 55 & $1.21+/-0.01$ & - & - & $2 /-1-$ & - & - \\
\hline & 30 & $1.12+/-0.01$ & - & - & $2 /-1-$ & - & - \\
\hline
\end{tabular}

Table 9. Fit parameters derived using Eq. (3) for hygroscopic growth factors at 30, 55, 75, and 90\% $R H$ during INDOEX

\begin{tabular}{llll}
\hline Time period & Dry particle diameter, $D p=50 \mathrm{~nm}$ & Dry particle diameter, $D p=150 \mathrm{~nm}$ & Dry particle diameter, $D p=250 \mathrm{~nm}$ \\
\hline 8 & $\mathrm{~A}=0.9990+/-0.0063$ & $\mathrm{~A}=1.0273+/-0.0210$ & $\mathrm{~A}=1.0335+/-0.0268$ \\
& $\gamma=-0.2250+/-0.0038$ & $\gamma=-0.2620+/-0.0122$ & $\gamma=-0.2789+/-0.0154$ \\
11 & $\mathrm{~A}=0.9829+/-0.0192$ & $\mathrm{~A}=0.9756+/-0.0169$ & $\mathrm{~A}=1.0042+/-0.0229$ \\
& $\gamma=-0.2427+/-0.0118$ & $\gamma=-0.2831+/-0.0102$ & $\gamma=-0.2761+/-0.0135$ \\
\hline
\end{tabular}

90\%. Three different types of hygroscopic growth (morehygroscopic, less-hygroscopic, nearly hydrophobic) could be distinguished at $90 \% R H$, whereas just two groups could be distinguished at $75 \% R H$ and one type of hygroscopic growth at 30 and $55 \% R H$.

A key finding is that clean marine air masses could clearly be distinguished from strongly polluted air masses by taking into account only the hygroscopic characteristics that identify the occurrence of different hygroscopicity modes, the hygroscopic growth factors of these modes, and their number fractions. Another finding is that marine air masses that had passed over a continent several days before reaching the ship, showed significant differences in these parameters, compared with clean marine air masses.
In general, relatively high growth factors of morehygroscopic particle fractions correspond well with the measured chemical inorganic composition. For most time periods, ammonium ions and sulfate ions dominated the molar distribution, signifying that the major inorganic compounds were hygroscopically active material, such as ammonium sulfate, ammonium bisulfate, and sulfuric acid.

The growth factors for the more-hygroscopic particle mode decreased slightly for accumulation mode particles $(150 \mathrm{~nm}$ and $250 \mathrm{~nm}$ particles) during time periods when highly anthropogenically influenced air masses were encountered. However, this decrease was much more significant for growth factors measured at lower $R H$ (30 and 55\%), rather than at higher $R H$ (75 and 90\%). The hygroscopicity data 
obtained at $30,55,75$ and $90 \% R H$ were used to parameterize the growth factors of more-hygroscopic particles as a function of $R H$. This parameterization reflects the general relationship that differences in growth factors due to changes in air mass are more pronounced at lower $R H(\leq 55 \%)$.

Continentally influenced air masses showed a strong increase in aerosol mass, which also corresponded with rather high amounts of carbonaceous material. In general, this occurrence of carbonaceous material was correlated with the increase in light absorption coefficient and with the occurrence of less-hygroscopic and nearly hydrophobic particle fractions in the hygroscopic growth distributions.

Although more-hygroscopic particles with relatively high growth factors were always detected (regardless of air mass), less-hygroscopic particle groups were only detected during those time periods when continentally influenced air masses prevailed. Furthermore, growth factors of this particle group were generally greater for INDOEX (Indian Ocean) than for Aerosols99 (Atlantic Ocean), which can be explained by different aging times during transport of the particles. Continentally influenced air masses were encountered more frequently during INDOEX than during Aerosols99, resulting in more frequent observations of less-hygroscopic particles.

A nearly hydrophobic particle group appeared with growth factors between 1.16 and 1.36, depending on the particle size. The occurrence of these nearly hydrophobic particles indicates a high anthropogenic influence. Air-mass back trajectories showed a transport time between 12 and 36 hours between the continent and the ship for this time period. Furthermore, the maximum concentration of elemental carbon during both cruises occurred during this time period.

The number fractions of less-hygroscopic particles ranged from few percent up values higher than $60 \%$ depending on dry particle size and air mass type. In general, the highest number fractions were found for the biomass burning air mass and for the continentally influenced Subcontinent air mass indicating high anthropogenic influence.

Less-hygroscopic particles showed a sharp increase in hygroscopic growth factor from $75 \%$ to $90 \% R H$. One reason for this increase might be the presence of organic material, which supposedly shows different hygroscopic growth than that of inorganic salts (Saxena et al., 1995).

Acknowledgements. We are grateful for the support and cooperation of the NOAA PMEL group, who gave us the opportunity to participate in these two field studies. We also thank the participants of the cruise from the University of Washington and PMEL for the brilliant teamwork during and after the cruise.

This work was supported by the "Bundesministerium für Bildung, Wissenschaft, Forschung und Technik" (BMBF), under the project title "Schließungs- und Charakterisierungs-Experiment am anthropogen beeinflussten Aerosol über dem Indischen Ozean", and project-number 01 LA-9830/0.

\section{References}

Bates, T. S., Quinn, P. K., Coffman, D. J., Johnson, J. E., Miller, T. L., Covert, D. S., Wiedensohler, A., Leinert, S., Nowak, A., and Neusüß, C.: Regional physical and chemical properties of the marine boundary layer aerosol across the Atlantic during Aerosols99: An overview, J. Geophys. Res., 106, 20 767-20 782, 2001.

Berg, H. O., Swietlicki, E., and Krejci, R.: Hygroscopic growth of aerosol particles in the marine boundary layer over the $\mathrm{Pa}$ cific and Southern Oceans during the First Aerosol Characterization Experiment (ACE 1), J. Geophys. Res., 103, 16 535-16545, 1998.

Berner, A., Lurzer, C., Pohl, F., Preining, O., and Wagner, P.: The size distribution of the urban aerosol in Vienna, Sci. Total Environ., 13, 245-261, 1979.

Charlson, R. J., Lovelock, J. E., Andreae, M. O., and Warren, S. G.: Oceanic phytoplankton, atmospheric sulphur, cloud albedo and climate, Nature, 326, 655-661, 1987.

Charlson, R. J., Schwartz, S. E., Hales, J. M., Cess, R. D., Coakley Jr., J. A., Hansen, J. E., and Hofmann, D. J.: Climate forcing by anthropogenic aerosols, Science, 255, 423-430, 1992.

Houghton, J. T., Ding, Y., Griggs, D. J., Noguer, M., van der Linden, P. J., and Xiaosu, D.: IPCC: Climate change 2001: The Scientific Basis, Cambridge University Press, 2001.

Kulmala, M., KoRHonen, P., Vesala, T., Hansson, H. C., Noone, K., and Svenningsson, B.: The effect of hygroscopicity on cloud droplet formation, Tellus, 48B, 347-360, 1996.

Liu, B. Y. H., Pui, D. Y. H., Whitby, K. T., Kittelson, D. B., Kousaka, Y., and McKenzie, R. L.: The aerosol mobility chromatograph: a new detector for sulfuric acid aerosols, Atmos. Environ., 12, 99-104, 1978.

McMurry, P. H. and Stolzenburg, M. R.: On the sensitivity of particle size to relative humidity for Los Angeles aerosols, Atmos. Environ., 23, 497-507, 1989.

Neusüß, C., Gnauk, T., Plewka, A., Herrmann, H., and Quinn, P. K.: Carbonaceous aerosol over the Indian Ocean: OC/EC fractions and speciations from size-segregated samples taken onboard the R/V Ron Brown, J. Geophys. Res., in press 2002.

Ogren, J. A. and Charlson, R. J.: Implications for models and measurements of chemical inhomogeneities among cloud droplets, Tellus, 44B, 489-504, 1992.

Philip, J. S., Liu, D. Y., Noble, C. A., and Prather, K. A.: Size and chemical characterization of individual particles resulting from biomass burning of local Southern California species, Environ. Sci. Technol., 33 (18), 3068-3076, 1999.

Quinn, P. K., Coffman, D. J., Kapustin, V. N., Bates, T. S., and Covert, D. S.: Aerosol optical properties in the marine boundary layer during ACE 1 and the underlying chemical and physical aerosol properties, J. Geophys. Res., 103, 16 547-16563, 1998.

Quinn, P. K., Coffman, D. J., Bates, T. S., Miller, T. L., Johnson, J. E., Voss, K., Welton, E. J., and Neusüß, C.: Dominant aerosol chemical components and their contribution to extinction during the Aerosols99 cruise across the Atlantic, J. Geophys. Res., 106, 20783-20 810, 2001.

Quinn, P. K., Coffman, D. J., Bates, T. S., Miller, T. L., Johnson, J. E., Welton, E. J., Neusüß, C., Miller, M., and Sheridan, P. J.: Aerosol optical properties during INDOEX 1999: Means, Variability, and controlling factors, J. Geophys. Res., in press 2002. 
Saxena, P., Hildemann, L. M., McMurry, P. H., and Seinfeld, J. H.: Organics alter hygroscopic behavior of atmospheric particles, J. Geophys. Res., 100 (D9), 18 755-18 770, 1995.

Seinfeld, J. H. and Pandis, S. N.: Atmospheric chemistry and physics: From air pollution to climate change, Wiley \& Sons Inc., New York, 508, 1998.

Svenningsson, B., Hansson, H. C., Wiedensohler, A., Ogren, J. A., Noone, K. J., and Hallberg, A.: Hygroscopic growth of aerosol particles in the Po Valley, Tellus, 44B, 556-569, 1992.

Svenningsson, B., Hansson, H. C., Martinsson, B., Wiedensohler, A., Swietlicki, E., Cederfelt, S.-I., Wendisch, M., Bower, K. N., Choularton, T. W., and Colvile, R. N.: Cloud droplet nucleation scavenging in relation to the size and hygroscopic behavior of aerosol particles, Atmos. Environ., 31 (6), 2463-2475, 1997.

Swietlicki, E., Zhou, J., Berg, O. H., Martinsson, B. G., Frank, G., Cederfelt, S. I., Dusek, U., Berner, A., Birmili, W., Wiedensohler, A., Yuskiewicz, B., and Bower, K. N.: A closure study of sub-micrometer aerosol particle hygroscopic behavior, Atmos. Research, 50, 205-240, 1999.
Swietlicki, E., Zhou, J., Covert, D. S., et al.: Hygroscopic properties of aerosol particles in the eastern Northern Atlantic during ACE2, Tellus, 52B, 201-227, 2000.

Tang, I. N. and Munkelwitz, H. R.: Composition and temperature dependence of the deliquescence properties of hygroscopic aerosols, Atmos. Environ., 27A, 467-473, 1993.

Tang, I. N. and Munkelwitz H. R.: Water activities, densities, and refractive indices of aqueous sulfate and sodium nitrate droplets of atmospheric importance, J. Geophys. Res., 99, 18 801-18 808, 1994.

Taylor, J. P. and McHaffie, A.: Measurements of Cloud Susceptibility, J. Atmos. Sci., 51 (10), 1298-1306, 1993.

Twomey, S.: Pollution and planetary albedo, Atmos. Environ., 8, 1251-1256, 1974.

Twomey, S.: Atmospheric aerosols, Elsevier, New York, 279-287, 1977.

Voutilainen, A., Stratmann, F., and Kaipio, J. P.: A nonhomogenous regularization method for the estimation of narrow aerosol size distribution, J. Aerosol Sci., 31 (12), 1433-1445, 2000 . 